Research Article

\title{
Characteristic Analysis of Digital Emulsion Relief Valve Based on the Hydraulic Loading System
}

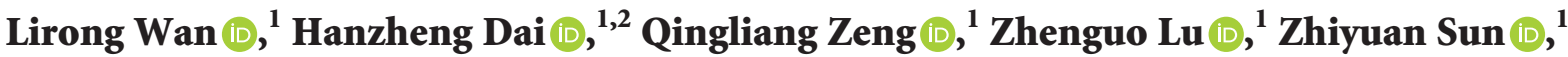 \\ Mingqian Tian, ${ }^{1}$ and Yanjie Lu $\mathbb{D}^{1}$ \\ ${ }^{1}$ College of Mechanical and Electronic Engineering, Shandong University of Science and Technology, Qingdao 266590, China \\ ${ }^{2}$ Department of Mechanical Design and Manufacturing, College of Mechanical and Architectural Engineering, \\ Taishan University, Tai'an 271000, China
}

Correspondence should be addressed to Hanzheng Dai; dhz@tsu.edu.cn

Received 24 March 2020; Revised 11 October 2020; Accepted 15 October 2020; Published 4 November 2020

Academic Editor: Francisco Beltran-Carbajal

Copyright (c) 2020 Lirong Wan et al. This is an open access article distributed under the Creative Commons Attribution License, which permits unrestricted use, distribution, and reproduction in any medium, provided the original work is properly cited.

In the hydraulic loading system, the performance of digital relief valve plays an important role in the dynamic response of load. However, the research on large-flow emulsion relief valve is still far from perfect. In this paper, digital relief valve is taken as the research object. Based on pilot-operated relief valve, a digital control scheme using a linear stepping motor is adopted to regulate the working pressure of relief valve. The structure of relief valve is analyzed and optimized from the aspects of dynamic and internal flow field characteristics to obtain a good working performance. To obtain its accurate working characteristic, the structural model and digital control system of relief valve are established by AMESim and Simulink, respectively, for electrohydraulic cosimulation. The results show that digital relief valve has a better characteristic of real-time dynamic pressure regulation. Therefore, the digital control system could improve the dynamic performance of relief valve, and the design of digital relief valve structure is reasonable and feasible. The simulation method employed in this paper provides a better theoretical basis and reference for the comprehensive research of digital large-flow emulsion relief valves based on the hydraulic loading system.

\section{Introduction}

In the hydraulic loading system, the power to weight ratio of the hydraulic components is large, the rigidity of antiload is large, the response of the system is fast, and the adaptability is good. Therefore, the hydraulic loading system applied to the loading system of product performance test-bed is particularly obvious, especially in the medium- and highpower transmission system $[1,2]$. The principle of the hydraulic loading system is to transform mechanical energy of the tested transmission system into hydraulic energy to realize passive loading. The adjustment of loading is carried out by digital relief valve; therefore, the performance of digital relief valve plays a key role in the dynamic response characteristics of the load. Pilot-operated relief valve is the main structure of the digital relief valve, and so its characteristics have a significant effect on the performance of digital relief valve. Many scholars have done a lot of research on the characteristic analysis of relief valve by theoretical and test studies. Franc used both analytical and numerical approaches to design a two-stage pressure-relief valve and tested its performance, and it was found that it is appropriate for use in a water-hydraulics system [3]. Ma et al. investigated the dynamic instability characteristic of pressure relief valve by the experimental research that was performed by considering the influence factors of flow rate, set pressure, and inlet pipe length [4]. Cheng proposed the recommended range of the pilot valve flow when the design of the main valve was opened through the valve and the data fitting analysis based on a certain type of relief valve [5]. However, the theoretical analysis results may deviate greatly from the actual results; therefore theoretical and simulation studies have been carried out to analyze more accurately the static and dynamic characteristics of the pilot relief valve. Dasgupta et al. studied the dynamics of a pilot-operated pressure relief valve and a proportional-controlled-piloted relief valve 
using the bond graph simulation technique. The critical design parameters with a significant effect on the transient response of the system were identified $[6,7]$. Shu-jun et al. established the dynamic model of PWM digital proportional relief valve for vehicle power shift, carrying out the simulation calculation with MSC EASY5, and identified the optimal damping hole parameters [8]. Some scholars analyzed the dynamic characteristics of the pilot-operated relief valve by theoretical method and Simulink simulation [9-14]. Moreover, some scholars analyzed the dynamic characteristics of the pilot-operated relief valve by the theoretical method and AMESim simulation [15-19]. Qing-liang Zeng et al. used AMESim and Simulink to analyze dynamic characteristics of the digital large flow emulsion relief valve, respectively [20]. The research on relief valve has mainly focused on the design of the working principle and the simulation analysis of dynamic characteristics based on mathematical model. However, few literature studies are found on the research of electrohydraulic cosimulation of the dynamic response characteristics of digital relief valve.

The flow field simulation research of relief valve mostly focuses on the simulation analysis of local structure flow field, most of which focuses on the two-dimensional steadystate simulation of main valve or pilot valve port [21-23]. Tian et al. designed the structure of a digital pressure relief valve of water-based hydraulic. The difference in the valve element cavity volume and roundedness of water pressure relief valve's cavitation flow field were simulated and analyzed [24]. Yuan et al. modeled and analyzed a pilot relief valve and presented the flow force by using computational fluid dynamics (CFD) method, which brought a systematic method for designing and analyzing similar valves [25]. Bossard et al. analyzed the dynamic performance of the Target Rock Pressure Relief Valve by using Generalized Fluid System Simulation Program (GFSSP), which would accommodate both the fluid dynamic features of the valve operation and the kinematic characteristics of the valve during pressure relief valve operation [26]. The research on the flow field analysis of relief valve ignores the change of flow field during the opening process of relief valve. Due to the coupling effect of fluid of various parts, it is difficult to get accurate results for the analysis of the local flow field alone.

In this paper, digital relief valve will be comprehensively analyzed from the aspects of its dynamic characteristics, flow field distribution characteristics, and electrohydraulic cosimulation analysis.

\section{Mathematical and Simulation Models}

To improve the dynamic performance of relief valve, this paper adopts a digital control scheme using a linear stepping motor to regulate the working pressure based on pilotoperated relief valve [20]. The structure and principle of the digital relief valve are shown in Figure 1.

$p$ is inlet pressure of main valve; $p_{1}$ is inlet pressure of pilot valve; $p_{2}$ is pressure of main valve upper cavity; $A_{x}$ is the area of pilot valve seat hole; $A_{1}$ is area of main valve lower cavity; $A_{2}$ is area of main valve upper cavity; $q$ is flow rate of relief valve; $q_{1}$ is flow rate of pilot valve damping hole; $q_{2}$ is flow rate of main valve upper cavity; $V_{0}$ is volume of main valve inlet cavity; $V_{1}$ is volume of pilot valve front cavity; $V_{2}$ is volume of main valve upper cavity; $M$ is mass of main valve-core; $m$ is mass of pilot valve-core; $x$ is displacement of pilot valve-core; $y$ is displacement of main valve-core.

The principle control diagram of digital relief valve is shown in Figure 1(a), where the working pressure can be obtained in real time through the pressure sensor at the inlet of relief valve. By comparing the actual pressure with the preset pressure, the controller obtains the mathematical relationship between linear stepping increment of linear stepping motor, spring preload of pilot valve, and the inlet pressure of main valve. According to the results of pressure comparison, the rotation and step number of the stepping motor are controlled by the driving circuit to change the precompression of pilot valve spring, and then the precompression force of the spring is adjusted to realize the real-time dynamic pressure regulation. The structure diagram of the digital relief valve is shown in Figure 1(b), and relief valve is composed of main valve and pilot valve.

2.1. Mathematical Model of Relief Valve. As is shown in Figure 1(a), the dynamic mathematical model of relief valve is established based on the two basic principles of force balance and flow continuity. The mathematical model is described by the following equations. The force balance equation of pilot valve-core is shown in

$$
p_{1} A_{x}=m \frac{\mathrm{d}^{2} x}{\mathrm{~d} t^{2}}+B_{x} \frac{\mathrm{d} x}{\mathrm{~d} t}+K_{x}\left(x_{0}+x\right)+K_{s x} x,
$$

where $p_{1}$ is inlet pressure of pilot valve; $A_{x}$ is the area of pilot valve seat hole; $m$ is mass of pilot valve-core; $x$ is displacement of pilot valve-core; $B_{x}$ is kinematic viscous damping coefficient of pilot valve-core; $K_{x}$ is spring stiffness of pilot valve; $x_{0}$ is precompression of pilot valve spring; $K_{s x}$ is hydrodynamic force stiffness of pilot valve port.

The flow continuity equations of pilot valve are

$$
\begin{aligned}
q_{1}+q_{2} & =\frac{V_{1}}{E} \frac{\mathrm{d} p_{1}}{\mathrm{~d} t}+K_{q x} x+K_{c x} p_{1}, \\
q_{1} & =G_{1}\left(p-p_{1}\right)
\end{aligned}
$$

where $q_{1}$ is flow rate of pilot valve damping hole; $G_{1}$ is liquid guide of pilot valve damping hole; $p$ is inlet pressure of main valve; $q_{2}$ is flow rate of main valve upper cavity; $V_{1}$ is volume of pilot valve front cavity; $E$ is elastic modulus of emulsion; $K_{q x}$ is flow gain of pilot valve port; $K_{c x}$ is pressure-flow gain of pilot valve port.

The force balance equation of the main valve-core is

$$
p A_{1}-p_{2} A_{2}=M \frac{\mathrm{d}^{2} y}{\mathrm{~d} t^{2}}+B_{y} \frac{\mathrm{d} y}{\mathrm{~d} t}+K_{y}\left(y_{o}+y\right)+K_{s y} y,
$$

where $p_{2}$ is pressure of main valve upper cavity; $A_{1}$ is area of main valve lower cavity; $A_{2}$ is area of main valve upper cavity; $M$ is mass of main valve-core; $y$ is displacement of main valve-core; $B_{y}$ is kinematic viscous damping coefficient 


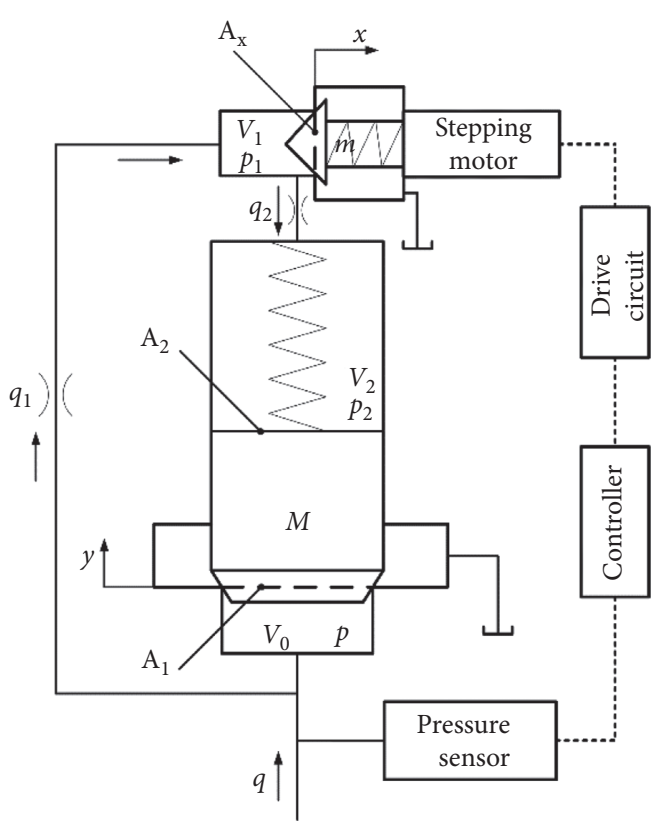

(a)

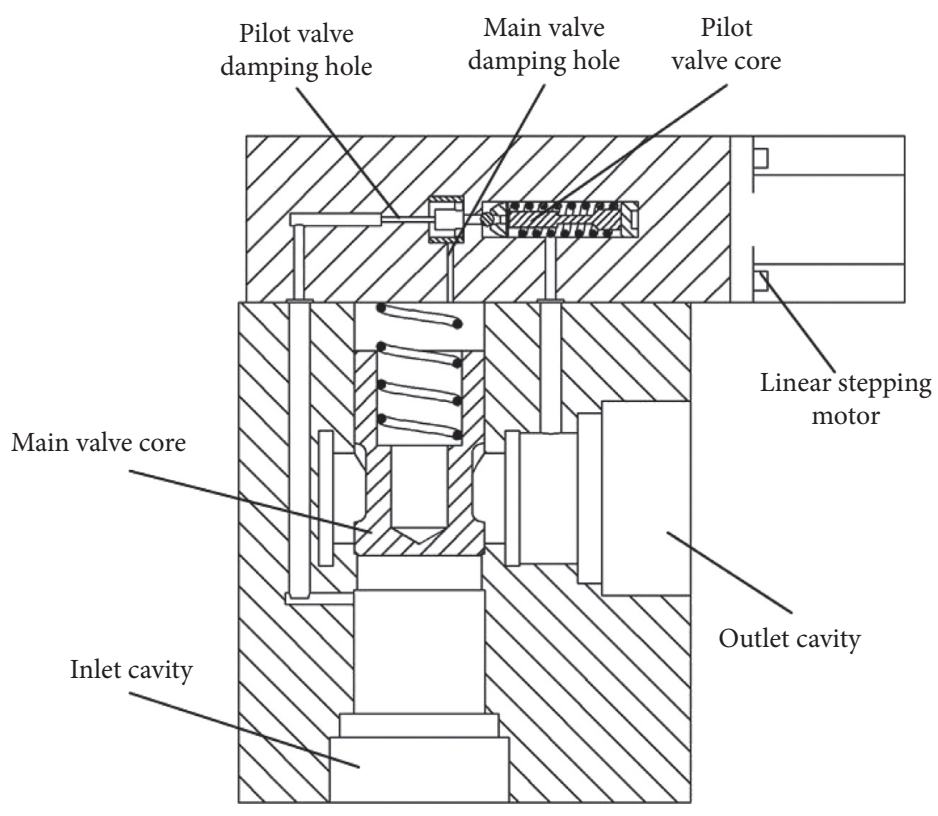

(b)

FIgURE 1: Structure and principle diagram of digital relief valve. (a) Principle control diagram. (b) Structure diagram.

of main valve-core; $K_{y}$ is spring stiffness of main valve; $y_{o}$ is precompression of main valve spring; $K_{s x}$ is hydrodynamic force stiffness of main valve port.

The flow continuity equations of main valve are

$$
\begin{aligned}
& q=q_{1}+K_{q y} y+K_{c y} p+\frac{V_{0}}{E} \frac{\mathrm{d} p}{\mathrm{~d} t}+A_{1} \frac{\mathrm{d} y}{\mathrm{~d} t}, \\
& q_{2}=G_{2}\left(p_{2}-p_{1}\right)=A_{2} \frac{\mathrm{d} y}{\mathrm{~d} t}-\frac{V_{2}}{E} \frac{\mathrm{d} p_{2}}{\mathrm{~d} t},
\end{aligned}
$$

where $q$ is flow rate of relief valve; $V_{0}$ is volume of main valve inlet cavity; $K_{q y}$ is flow gain of main valve port; $K_{c y}$ is pressure-flow gain of pilot valve port; $G_{2}$ is liquid guide of main valve damping hole; $V_{2}$ is volume of main valve upper cavity.

In order to draw the control block diagram for Simulink simulation, the above equations are Laplace-transformed, and the following equations are thus obtained:

$$
\begin{aligned}
x(s)= & \frac{1}{m s^{2}+B_{x} s+K_{x}+K_{s x}}\left[p_{1}(s) A_{x}-K_{x} x_{0}\right], \\
p_{1}(s)= & \frac{1}{\left(V_{1} / E\right) s+G_{1}+K_{c x}} \\
& \cdot\left[G_{1} p(s)-K_{q x} x(s)+G_{2} p_{2}(s)-G_{2} p_{1}(s)\right], \\
y(s)= & \frac{1}{M s^{2}+B_{y} s+K_{y}+K_{s y}} \\
& \cdot\left[p(s) A_{1}-p_{2}(s) A_{2}-K_{y} y_{0}\right], \\
p(s)= & \frac{1}{K_{c y}+\left(V_{0} / E\right) s}\left[q(s)-G_{1} p(s)+G_{1} p_{1}(s)\right. \\
& \left.-\left(K_{q y}+A_{1} s\right) y(s)\right],
\end{aligned}
$$

$$
p_{2}(s)=\frac{1}{G_{2}+\left(V_{2} / E\right) s}\left[A_{2} s y(s)+G_{2} p_{1}(s)\right] .
$$

According to equations 5-9, the control block diagram of relief valve as shown in Figure 2 is obtained.

\subsection{Establishment of the Simulation Model}

2.2.1. AMESim Simulation Model. The dynamic characteristics of the relief valve refer to the working characteristics of the relief valve in the process from initial pressure to stable pressure when the pressure of valve orifice changes abruptly. The dynamic characteristics of relief valves are usually measured by pressure overshoot and pressure stabilization time.

To ensure the rationality of the structural parameters of relief valve, the physical structure simulation model of relief valve is built, using AMESim. The influences of important structural parameters of relief valve on its dynamic characteristics are analyzed and studied. According to the working principle of the hydraulic loading system and the structure of pilot-operated relief valve, AMESim simulation model of the hydraulic loading system is shown in Figure 3.

The motor connected to the variable displacement bidirectional hydraulic pump replaces the output shaft of the transmission system to test the load characteristics. The loading hydraulic pump is an oblique-axis bidirectional variable piston hydraulic pump, which can not only realize bidirectional loading but also expand the loading range. The emulsion is used as a driving medium. Because the actual working environment of relief valve is more complex, the main purpose of AMESim simulation is to analyze whether the designed relief valve structure can operate normally and 


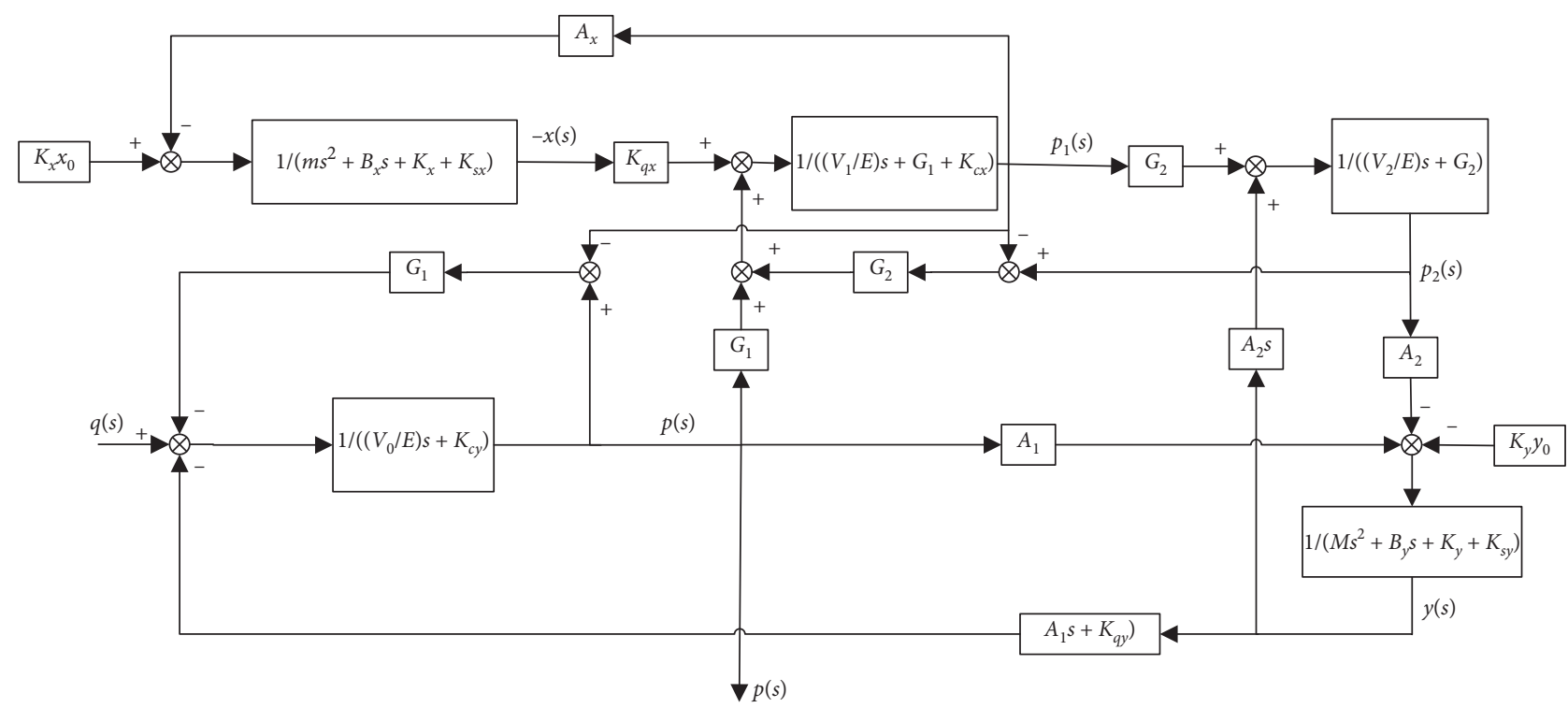

FIgURE 2: Control block diagram of relief valve.

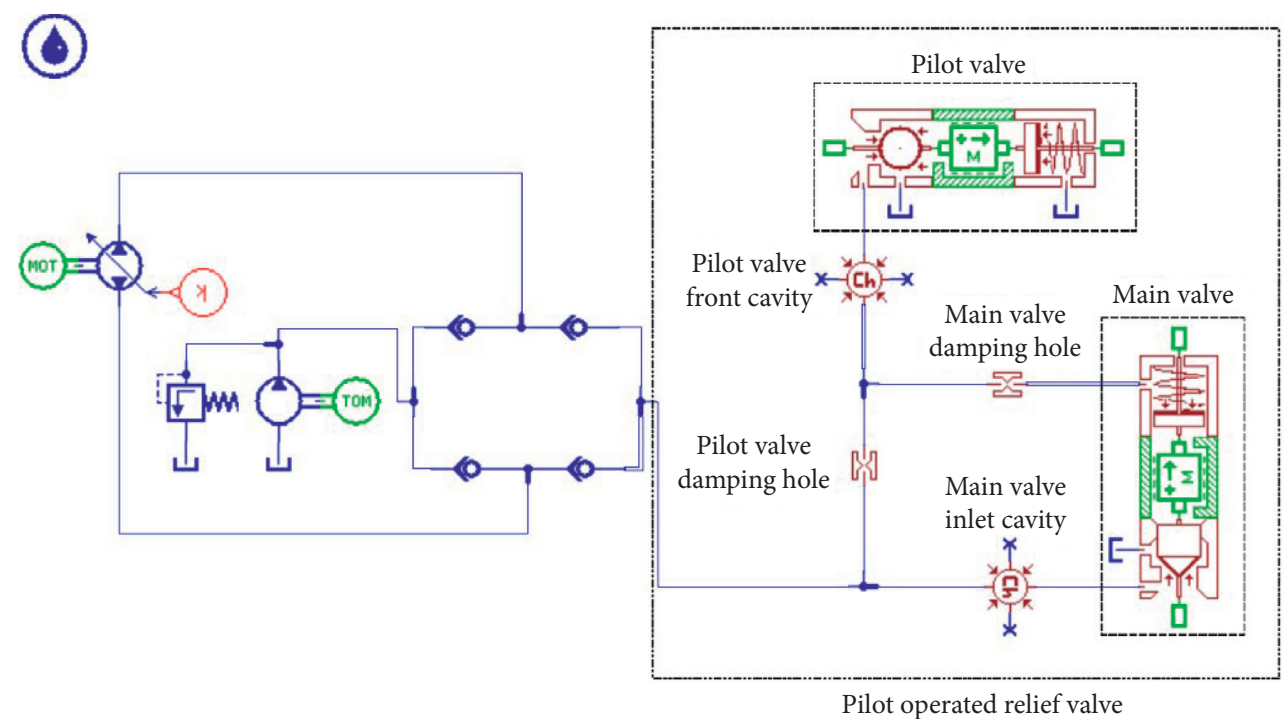

FIGURE 3: AMESim simulation model of hydraulic loading system.

to study the influence of the main structural parameters on the performance of relief valve. Therefore, the following simplifications and assumptions are made in the simulation to avoid the interference of redundant factors: (1) The bulk modulus and absolute viscosity of emulsion are constant. (2) The emulsion is an incompressible fluid, and its density is independent of temperature. (3) The components are ideal devices, and there is no leakage. (4) Cavitation is not considered.

2.2.2. Flow Field Simulation Model. To study the internal flow field distribution of relief valve during its working process, the flow field model of relief valve is established by using the analysis method of computational fluid dynamics (CFD) and PumpLinx software. The distributions of pressure, velocity, and turbulent kinetic energy in the opening process and steady state of the relief valve are simulated and analyzed. The structural parameters affecting the performance and reliability of the relief valve are obtained directly through the internal cloud chart and streamline chart.

In this paper, Pro/E is used to build the models of the relief valve cavity, main valve, and pilot valve. The cavity part is cut along the X-O-Y plane, and the model of the relief valve cavity is obtained as shown in Figure 4. The model of the relief valve cavity is imported into PumpLinx to establish the flow field simulation model. The relief valve model consists of a pilot valve, main valve, and pipelines on both sides. There are more interactive surfaces in the model; therefore a new interactive surface needs to be established. Interactive surfaces in the relief valve model are shown in Figure 5.

In Figure 5, 1 is inlet cavity and left side pipeline; 2 is main valve cavity and main valve piston surface; 3 is left side 


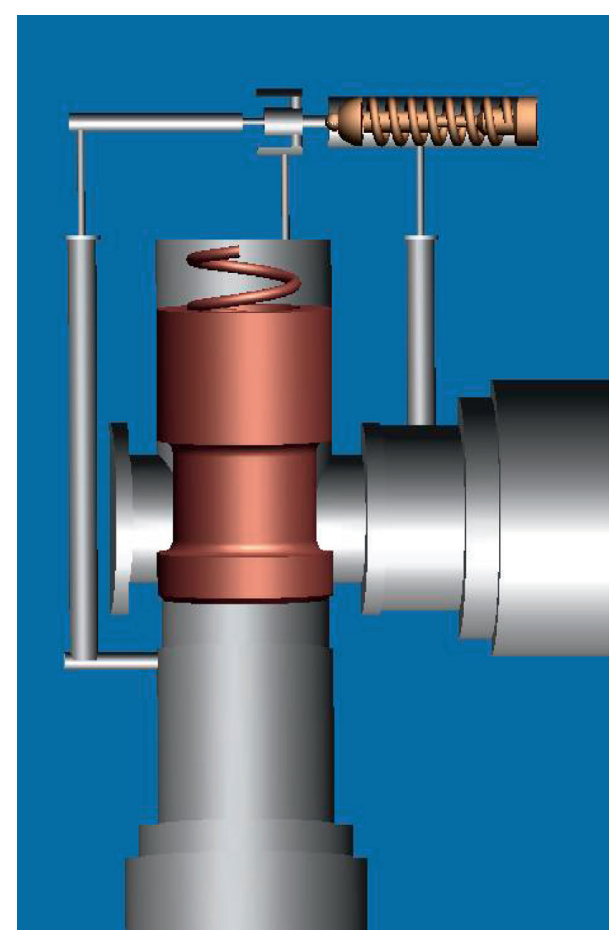

FIgUre 4: Model of relief valve cavity.

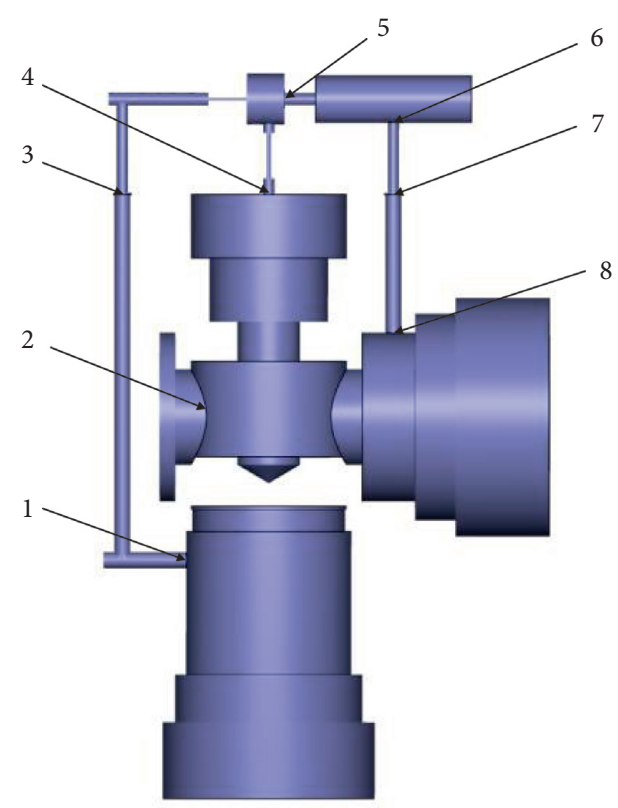

FIgURE 5: Interactive surfaces in relief valve model.

pipeline and pilot valve inlet cavity; 4 is pilot valve cavity and main valve upper cavity; 5 is pilot valve cavity and pilot valve body inlet cavity; 6 is pilot valve body surface and pilot valve cavity; 7 is pilot valve cavity and right side pipeline; 8 is right side pipeline and main valve cavity.

2.2.3. Cosimulation Model. The digital relief valve mainly includes a control system and a physical structure. To obtain the accurate working characteristics of digital relief valve, this paper builds a physical model by using AMESim software and establishes the digital control system of relief valve by using Simulink which has advantages in digital control and digital signal processing. The cosimulation is realized through the data interface of AMESim to Simulink. The digital relief valve can dynamically adjust the pressure of the system by the loading system controller to realize dynamic regulation of the load and simulate the load of actual working conditions, so as to obtain dynamic characteristics of digital relief valve in actual working conditions.

This article adopts linear stepping motor, whose parameters are shown in Table 1 . It is directly connected with pilot valve pressure-regulating spring, and the increment of the stepping motor can directly control the precompression of pilot valve pressure-regulating spring, thereby changing the spring pretightening force. In the model, the stepping motor is assumed to be in an ideal working state, so a detailed mathematical model or structural model of the stepper motor is not established, and only the motor step length is used as the gain. Since the pressure-regulating spring parameters in AMESim model do not include precompression, the stiffness of the pressure-regulating spring is added to the gain module of stepping motor to calculate the pretightening force of the pressure-regulating spring.

Therefore, the gain of stepping motor $g_{m}$ is

$$
g_{m}=\lambda \cdot K_{x}
$$

where $\lambda$ is the step of stepping motor; $K_{x}$ is the spring stiffness of pilot valve.

Then, according to equation (10), the calculated motor pulse gain is $0.143 \mathrm{~N}$.

PID parameter setting method adopts the engineering tuning method, which mainly relies on engineering experience and is carried out directly in the experiment of the control system. This method is simple and easy to master, so it is widely used in engineering practice. Therefore, the proportional coefficient, integral coefficient, and differential coefficient are 60,30, and 2, respectively.

The cosimulation model of digital relief valve in hydraulic loading system is shown in Figure 6.

Digital relief valve is used to control the pressure of the hydraulic loading system. The pressure value is measured by pressure sensor. The pressure value is imported into Simulink control subsystem, and increment of the step motor obtained by Simulink is imported into pilot valve model; thus, the cosimulation realizes the pressure regulation of digital relief valve and accurately controls the pressure value of the hydraulic loading system. For Simulink control model, the input variable is the pressure value of the hydraulic loading system, and the output variable is the increment of the step motor.

2.3. Initial Structural Parameters of Relief Valve. In this paper, the large flow digital relief valve is designed and analyzed. The rated pressure is $45 \mathrm{MPa}$ and the rated flow is $1000 \mathrm{~L} / \mathrm{min}$, with emulsion density of $890 \mathrm{~kg} / \mathrm{m}^{3}$ and emulsion dynamic viscosity of $0.792 \times 10^{-3} \mathrm{~Pa} \cdot \mathrm{s}$. According 
TABLE 1: Basic parameters of stepping motor.

\begin{tabular}{lcccc}
\hline Item & Screw diameter $(\mathrm{mm})$ & Lead $(\mathrm{mm})$ & Step angle $\left({ }^{\circ}\right)$ & Step $(\mathrm{mm})$ \\
\hline Value & 8 & 2 & 1.8 & 0.01 \\
\hline
\end{tabular}

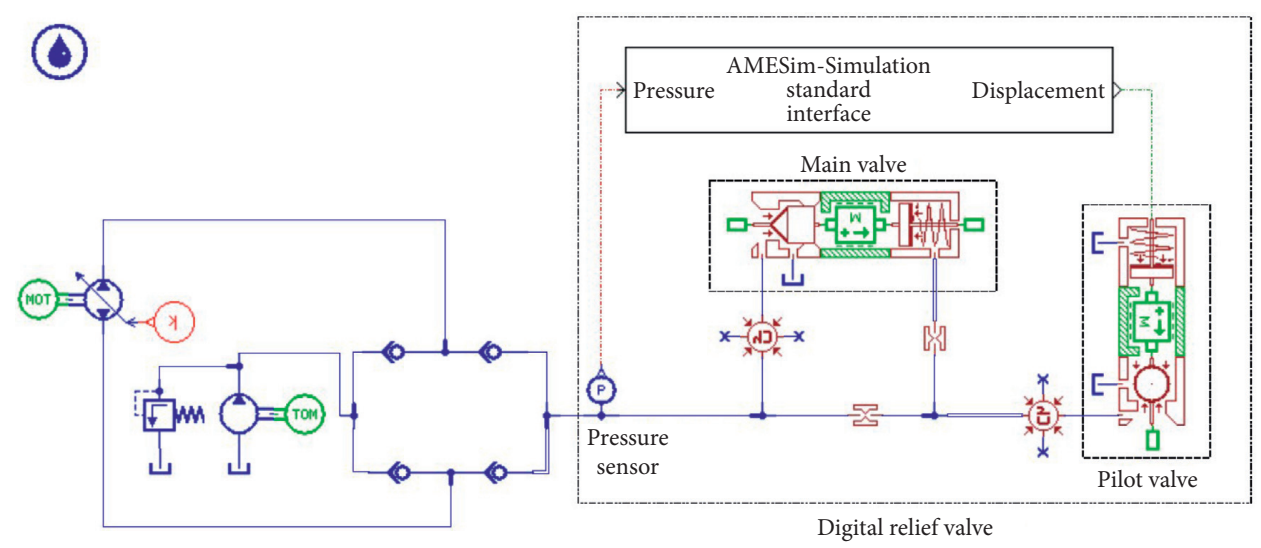

(a)

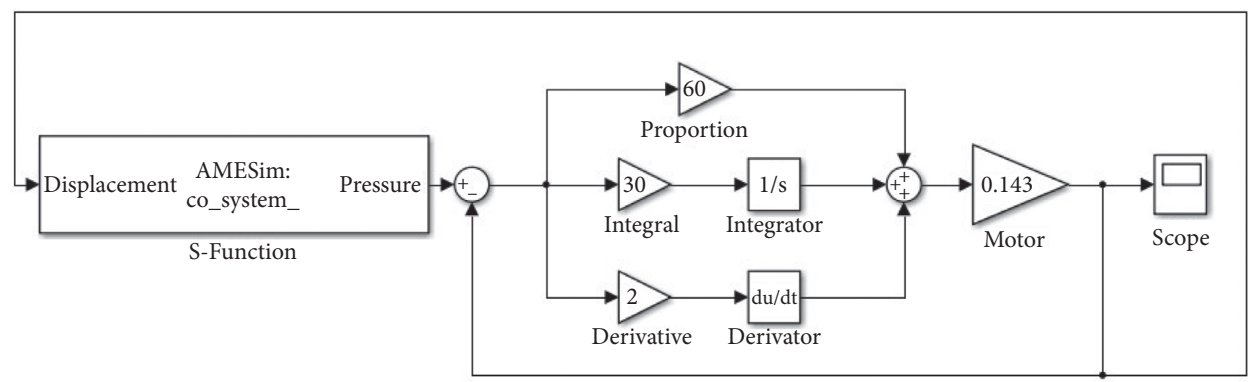

(b)

FIgUre 6: Cosimulation model of digital relief valve. (a) AMESim model of digital relief valve. (b) Simulink control model.

to structural design and characteristic analysis, the initial structural parameters of relief valve are as shown in Table 2.

\section{Results and Discussion}

3.1. Dynamic Characteristic Analysis Based on AMESim. For the relief valve applied to the emulsion pumping station, the influence of different structural parameters on the working characteristics of relief valve is obtained by AMESim [20]. This paper mainly focuses on working characteristics of the relief valve applied to the hydraulic loading system. Assuming that the mechanical efficiency of the variable pump is not taken into account, the dynamic characteristic curves are obtained by AMESim simulation, as is shown in Figure 7, based on the established model built in Figure 3.

As can be seen from Figure 7(a), the inlet pressure of main valve reaches $29.1 \mathrm{MPa}$ instantaneously at the initial stage of opening, and then the rate of growth slows down. The front cavity pressure of pilot valve increases slowly, and the peak pressure is up to $42.95 \mathrm{MPa}$ at $10.32 \mathrm{~ms}$. The peak inlet pressure of main valve is up to $46.87 \mathrm{MPa}$ at $10.02 \mathrm{~ms}$ and then gradually reaches a steady state. The opening times interval between pilot valve-core and main valve-core is short, indicating that relief valve works well. The steady-state
TABLE 2: Initial structural parameters of relief valve.

\begin{tabular}{lc}
\hline Structural parameter & Value \\
\hline Mass of pilot valve-core & $0.01 \mathrm{~kg}$ \\
Mass of main valve-core & $0.06 \mathrm{~kg}$ \\
Diameter of pilot valve seat hole & $3.8 \mathrm{~mm}$ \\
Diameter of main valve seat hole & $48 \mathrm{~mm}$ \\
Diameter of pilot valve damping hole & $1.2 \mathrm{~mm}$ \\
Diameter of main valve damping hole & $1.2 \mathrm{~mm}$ \\
Diameter of pilot valve-core & $5 \mathrm{~mm}$ \\
Diameter of main valve-core & $49 \mathrm{~mm}$ \\
Stiffness of pilot valve spring & $14.3 \mathrm{~N} / \mathrm{mm}$ \\
Stiffness of main valve spring & $9.0 \mathrm{~N} / \mathrm{mm}$ \\
Length of pilot valve damping hole & $12 \mathrm{~mm}$ \\
Length of main valve damping hole & $12 \mathrm{~mm}$ \\
\hline
\end{tabular}

inlet pressure of pilot valve is $38.90 \mathrm{MPa}$ at $17.90 \mathrm{~ms}$, and the steady-state inlet pressure of main valve is $45 \mathrm{MPa}$ at $18.70 \mathrm{~ms}$. The pressure overshoots are, respectively, $10.41 \%$ and $4.16 \%$. It can be seen from Figure $7(\mathrm{~b})$ that the change law of driving torque of variable pump is similar to that of inlet pressure of relief valve; therefore, the characteristics of relief valve directly determine the working characteristics of hydraulic loading system. 


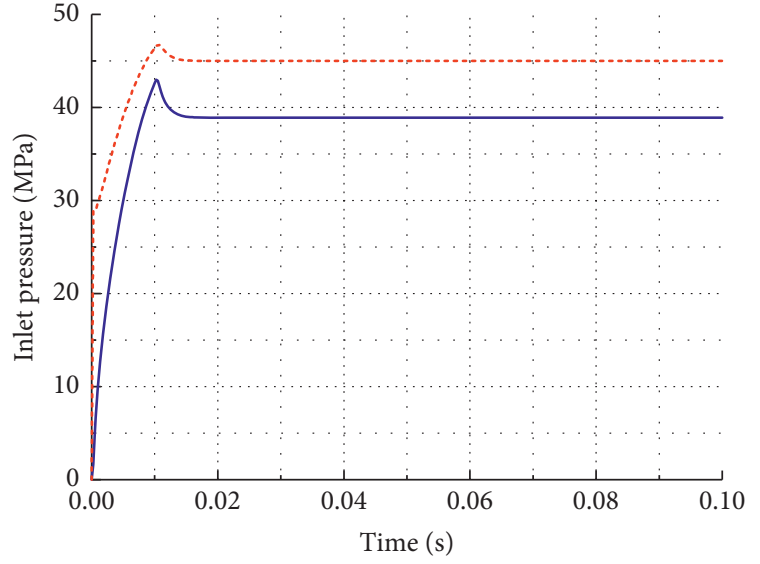

- Pilot valve
$\ldots$. Main valve

(a)

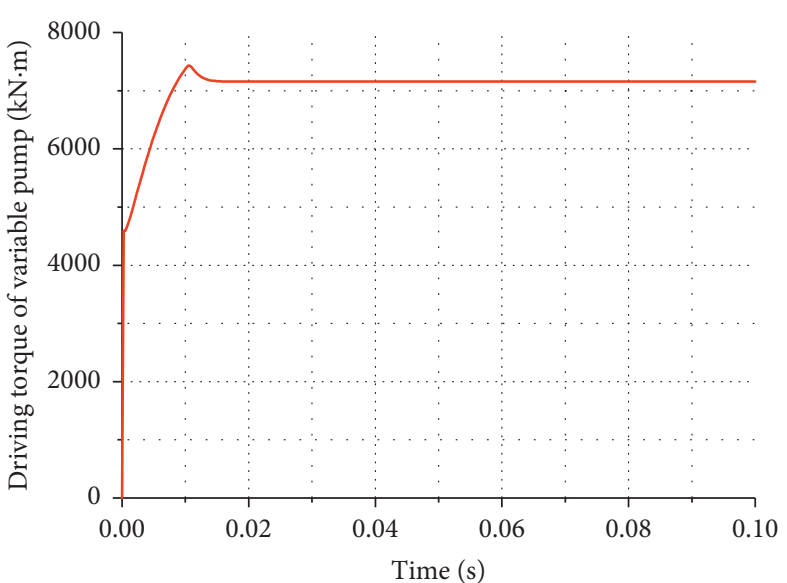

(b)

Figure 7: Dynamic characteristic curves. (a) Inlet pressure of relief valve. (b) Driving torque of variable pump.

3.1.1. Influence of Pilot Valve Spring on Dynamic Characteristics. The spring stiffness of pilot valve is changed and other structural parameters are kept unchanged. The inlet pressures of main valve and pilot valve are obtained, as is shown in Figure 8. The dynamic response indexes are shown in Figure 9.

It can be seen from the simulation results that the increase in the spring stiffness of pilot valve causes the preload force acting on pilot valve-core, and the steady-state pressure of relief valve increases accordingly. When the spring stiffness of pilot valve increases, the time to reach stable state is shortened, the pressure overshoot of relief valve decreases obviously, the steady pressure of relief valve is improved, and the time of dynamic response is shortened.

3.1.2. Influence of Main Valve Spring on Dynamic Characteristics. The spring stiffness of main valve is changed and other structural parameters are kept unchanged. The inlet pressures of main valve and pilot valve are obtained, as is shown in Figure 10, and the dynamic response indexes are shown in Figure 11.

It can be seen from the simulation results that the change of main valve spring stiffness has little influence on the dynamic response indexes, because the spring of main valve mainly plays a resetting role. The steady-state pressure of main valve and pilot valve increases with the increase of main valve spring stiffness. The pressure overshoot of main valve and pilot valve decreases with the increase of main valve spring stiffness, and the overshoot of pilot valve is larger than that of main valve. However, the change of main valve spring stiffness has little influence on the time to reach stable state.

3.1.3. Influence of Pilot Valve-Core Mass on Dynamic Characteristics. Pilot valve-core mass is changed and other structural parameters are kept unchanged. The inlet pressures of main valve and pilot valve are obtained, as is shown in Figure 12, and the dynamic response indexes are shown in Figure 13.

It can be seen from the simulation results that the change of pilot valve-core mass has no influence on the steady-state pressure of main valve and pilot valve. But pilot valve-core mass has a great influence on the time to reach stable state. According to the local enlargement diagram in Figures 12 and 13, it can be seen that the pressure overshoot of pilot valve and main valve increases with the increase of pilot valve-core mass. When the mass of the valve-core increases, the time to reach stable state is prolonged due to the increase of the number of oscillations.

3.1.4. Influence of Main Valve-Core Mass on Dynamic Characteristics. Main valve-core mass is changed and other structural parameters are kept unchanged. The inlet pressures of main valve and pilot valve are obtained, as is shown in Figure 14, and the dynamic response indexes are shown in Figure 15.

It can be seen from the simulation results that the change of main valve-core mass has little influence on the steadystate pressure and overshoot of main valve and pilot valve. According to the local enlargement diagrams in Figures 14 and 15 , it can be seen that the pressure overshoot of main valve increases when pilot valve-core mass increases to $0.08 \mathrm{~kg}$. When main valve-core mass increases to a certain value, the inlet pressure of main valve begins to oscillate, and the oscillation slows down with time and finally tends to be stable, which leads to the increase of overshoot and the time to reach stable state, but the stable state pressure does not change.

3.1.5. Influence of Damping Holes on Dynamic Characteristics. As is shown in Figure 1(b), relief valve includes two long and thin damping holes, namely, pilot valve damping hole and main valve damping hole. The pressure drop is generated by the throttling effect of the 


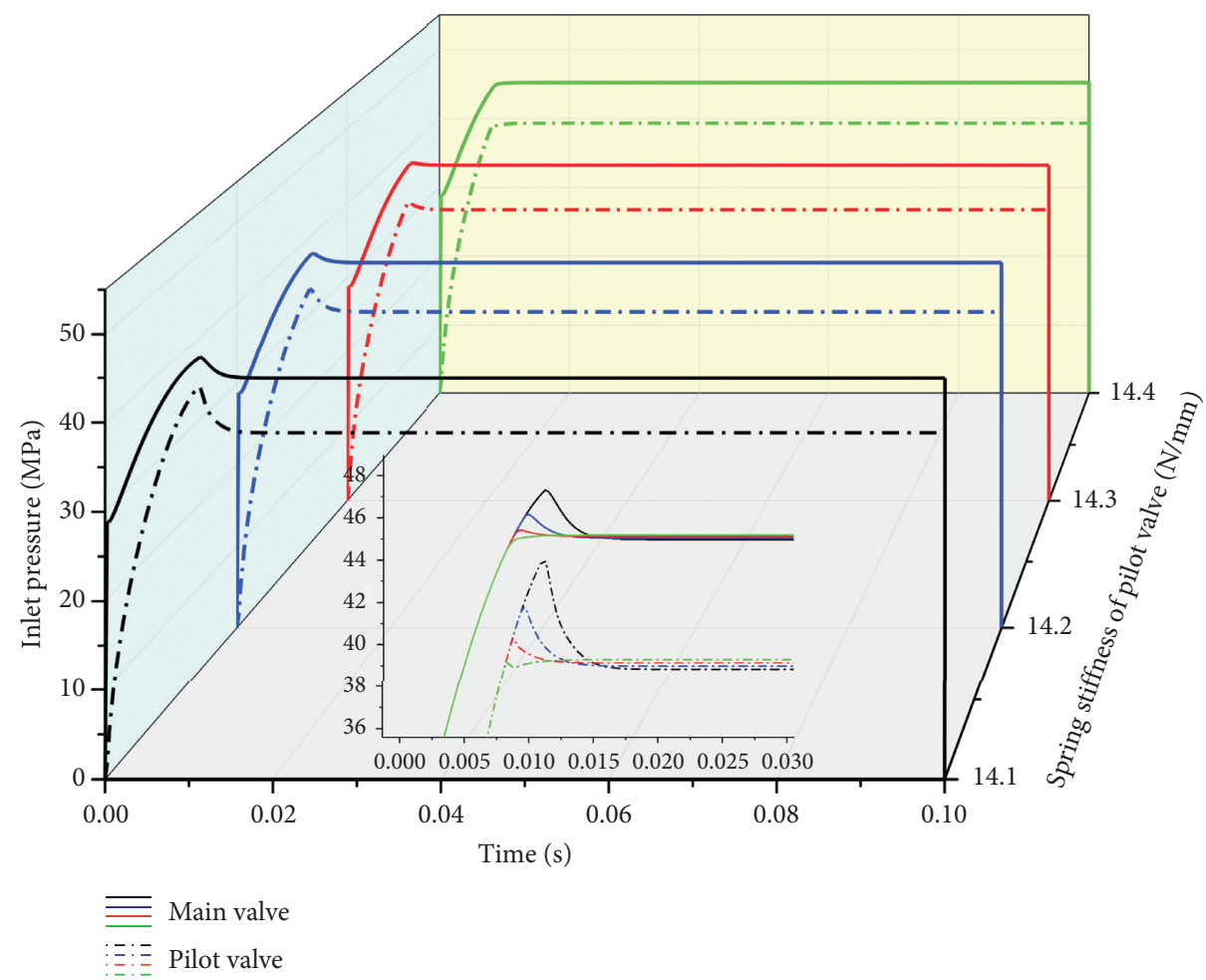

Figure 8: Influence of pilot valve spring on pressure.

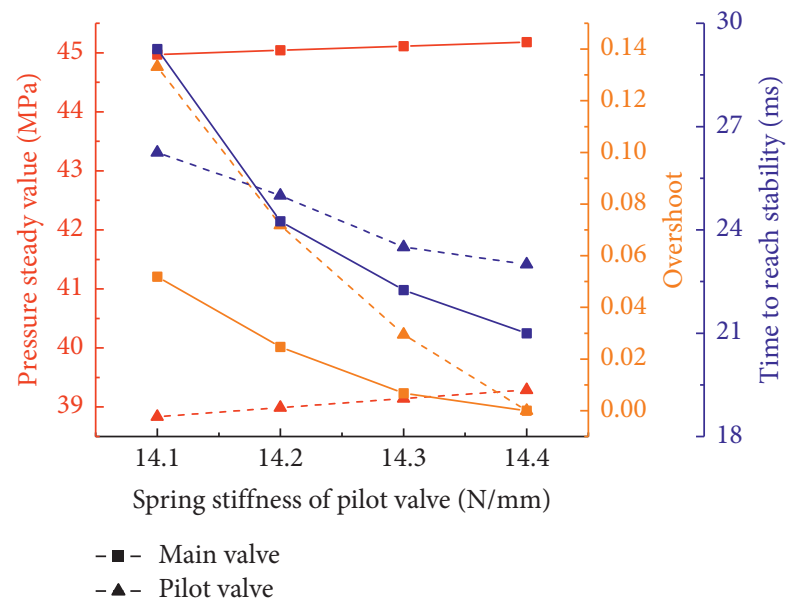

Figure 9: Dynamic response indexes.

damping holes to realize the relief function. In this paper, the influences of the diameter and length of two damping holes on the dynamic characteristics of relief valve are compared and analyzed.

(1) Influence of Damping Holes Diameter. The diameter of main valve damping hole is equal to that of pilot valve; the diameter of damping holes is changed and other structural parameters are kept unchanged. The inlet pressures of main valve and pilot valve are obtained as shown in Figure 16, and the dynamic response indexes are shown in Figure 17.

It can be seen from the simulation results that the diameter of damping holes has obvious influence on the dynamic response indexes. The steady-state pressure of main valve and pilot valve increases with the increase of damping holes diameter, and the time to reach stable state decreases gradually. The pressure overshoot of pilot valve decreases with the increase of damping holes diameter, but the overshoot of main valve increases with the increase of damping holes diameter.

(2) Influence of Damping Holes Length. The length of main valve damping hole is equal to that of pilot valve; the length of damping holes is changed and other structural parameters are kept unchanged. The inlet pressures of main valve and pilot valve are obtained as shown in Figure 18, and the dynamic response indexes are shown in Figure 19.

It can be seen from the simulation results that the steadystate pressure of main valve and pilot valve decreases with the increase of damping holes length. The pressure overshoot of pilot valve and main valve decreases with the increase of damping holes length, but the time to reach stable state increases with the increase of damping holes length.

3.2. Structural Optimization. According to the simulation analysis of structural characteristics and the analysis of factors influencing the dynamic response characteristics, the initial structure of relief valve is optimized to improve the dynamic response. The optimized structural parameters of relief valve are shown in Table 3.

The optimized structural parameters of relief valve are simulated and analyzed, and the comparison between initial results and optimized results is shown in Figure 20. 


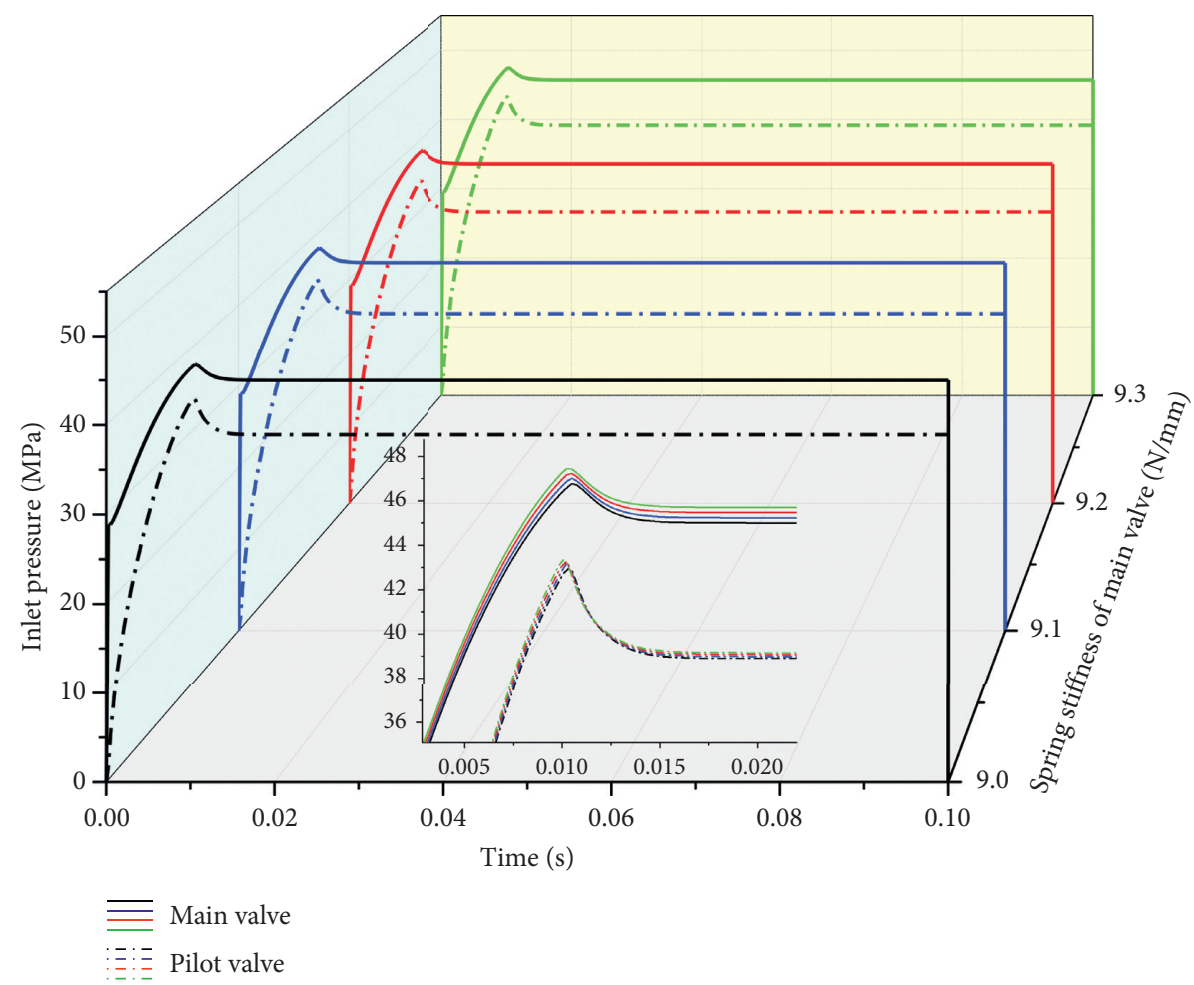

Figure 10: Influence of main valve spring on pressure.

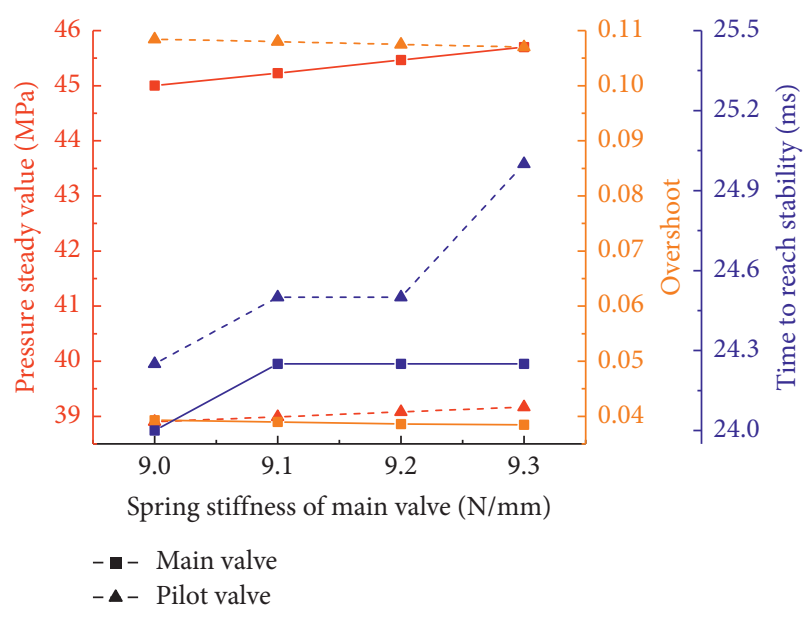

Figure 11: Dynamic response indexes.

As can be seen from Figure 20, after optimizing the structural parameters of relief valve, the steady-state inlet pressure of relief valve is $45 \mathrm{MPa}$ at $13.50 \mathrm{~ms}$, and the time to reach stable state is shortened by $5.2 \mathrm{~ms}$. The pressure overshoot of relief valve is $2.27 \%$, decreasing by $1.89 \%$.

3.3. Dynamic Characteristic Analysis Based on Simulink. According to the control block diagram of relief valve shown in Figure 2 and the optimized structure parameters, the Simulink simulation model of relief valve is established by using Simulink, and the dynamic response curves of pilot valve and main valve are obtained by calculation in Figure 21.
In this paper, the dynamic response simulation of relief valve is completed based on its physical structure parameters by AMESim, and the simulation of relief valve characteristics is based on relief valve mathematical model by MATLAB/ Simulink. Therefore, the simulation results are different. But it can be seen from Figure 21 that the time to reach stable state is short, the vibration frequency of main valve is less, and the stable inlet pressure is consistent with the AMESim simulation results in Figure 20. Therefore, relief valve has good dynamic response characteristics. At the same time, the comparison of the two simulation results verifies that relief valve has good working characteristics.

\subsection{Flow Field Analysis}

\subsubsection{Influencing Factors of Flow Field}

(1) Chamfer of Pilot Valve Seat Hole. The chamfer of pilot valve seat hole is changed under the same constraints and other structural parameters, and the simulation is carried out separately. The pressure distribution near pilot valve seat hole under stable condition is obtained, as is shown in Figure 22.

As can be seen from Figure 22, when pilot valve is just opened, there is a local low pressure area at the corner of pilot valve seat hole, which is prone to cavitation and affects the opening performance of pilot valve. The pressure at the corner of pilot valve seat hole without chamfer is the lowest. When the chamfer of pilot valve seat hole is 20 degrees, there is a circular low-pressure area behind the two sides of pilot valve-core, which easily generates eddy current; therefore 


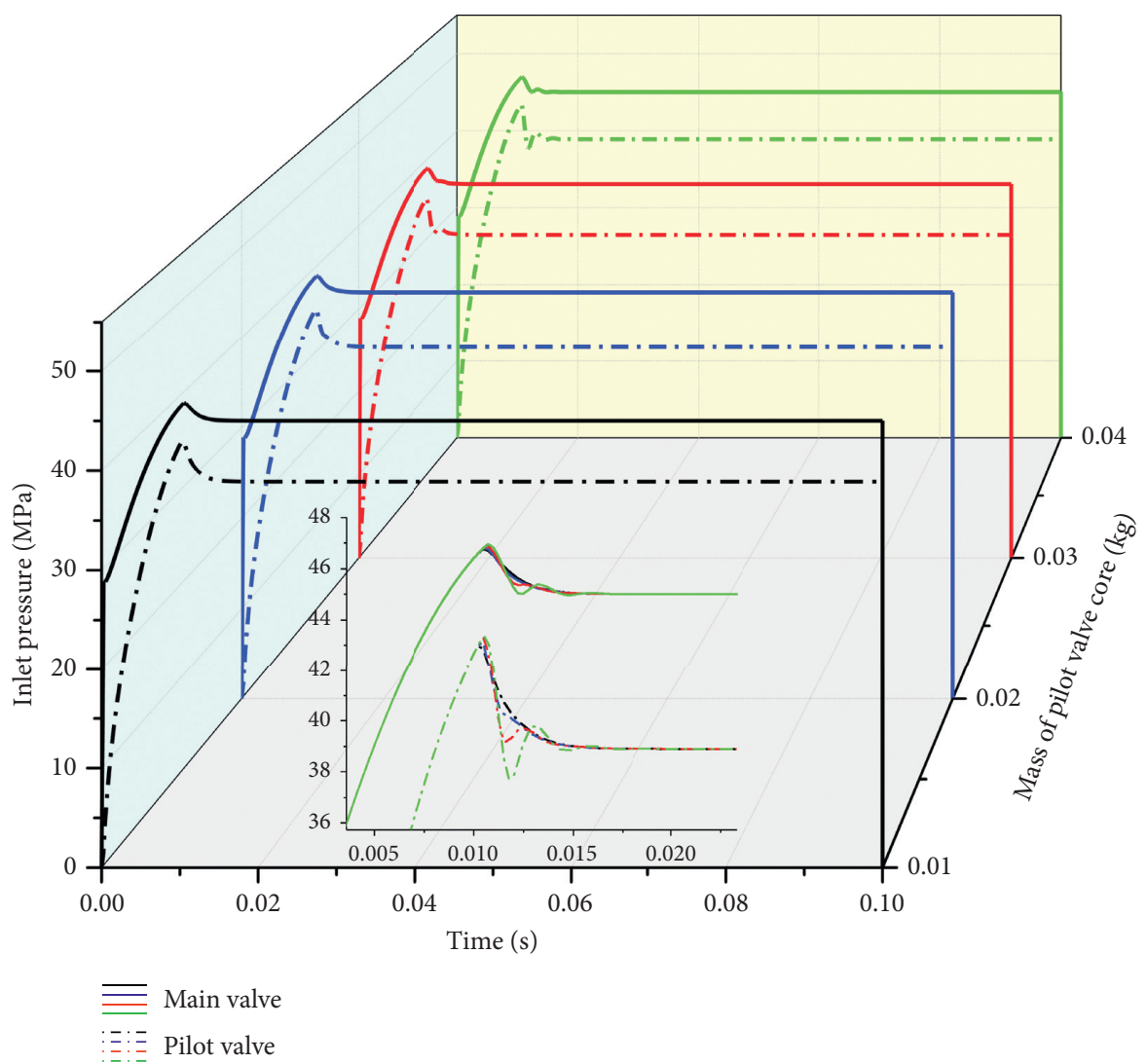

Figure 12: Influence of pilot valve-core mass on pressure.

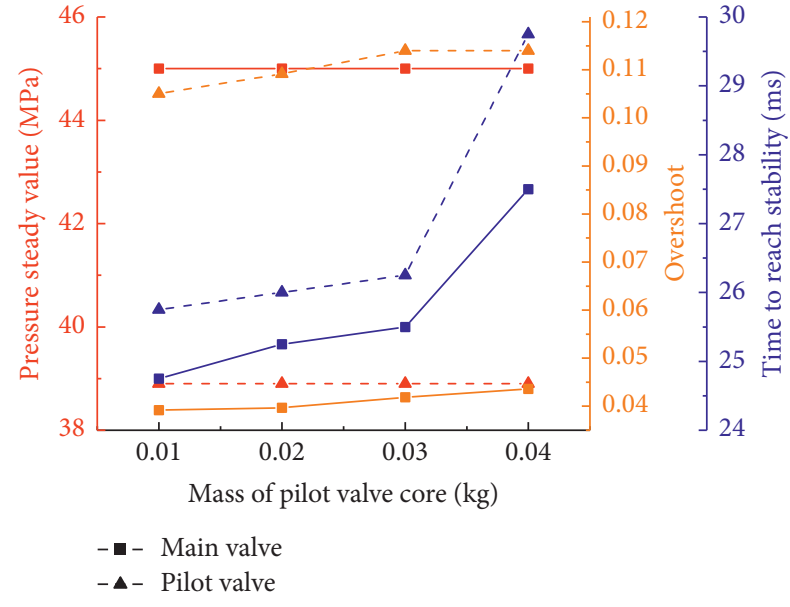

Figure 13: Dynamic response indexes.

the energy dissipation increases and the fluctuation of pilot valve-core also increases. When the chamfer of pilot valve seat hole is 45 degrees, the pressure distribution around pilot valve-core is well distributed; therefore, the working performance is better.

(2) Chamfer of Pilot Valve Damping Hole. The chamfer of pilot valve damping hole is changed under the same constraints and other structural parameters, and the simulation is carried out separately. The pressure distribution near damping hole under stable condition is obtained, as is shown in Figure 23.

As can be seen from Figure 23, when the damping hole is not chamfered, the pressure distribution at the damping hole is uniform and parallel, and there is no obvious low-pressure area. When the chamfer of pilot valve damping hole is 45 degrees, a sharp angle appears in the pressure distribution of the damping hole, the pressure in the middle of the hole is high, and the pressure on both sides is low; therefore, cavitation is easy to occur on both sides. When the chamfer of pilot valve damping hole is arc, the pressure in the area near the damping hole is curved and protruding outwards, and the pressure at the hole varies sharply, but the lowpressure area on both sides of the damping hole is small.

(3) Chamfer of Main Valve Seat Hole. The chamfer of main valve seat hole is changed under the same constraints and other structural parameters, and the simulation is carried out separately.

The pressure distribution near main valve seat hole under stable condition is obtained, as is shown in Figure 24.

As can be seen from Figure 24, when relief valve is in a stable state, there are different low-pressure areas above the valve seat hole. The low-pressure area of main valve seat hole with 45-degree chamfer is the largest, which is prone to cavitation. When the chamfer of main valve seat hole is 30 degrees, the pressure drop distribution is the smoothest; therefore, the valve has the best performance. When the chamfers of main valve seat hole are 45 degrees and arc, the 


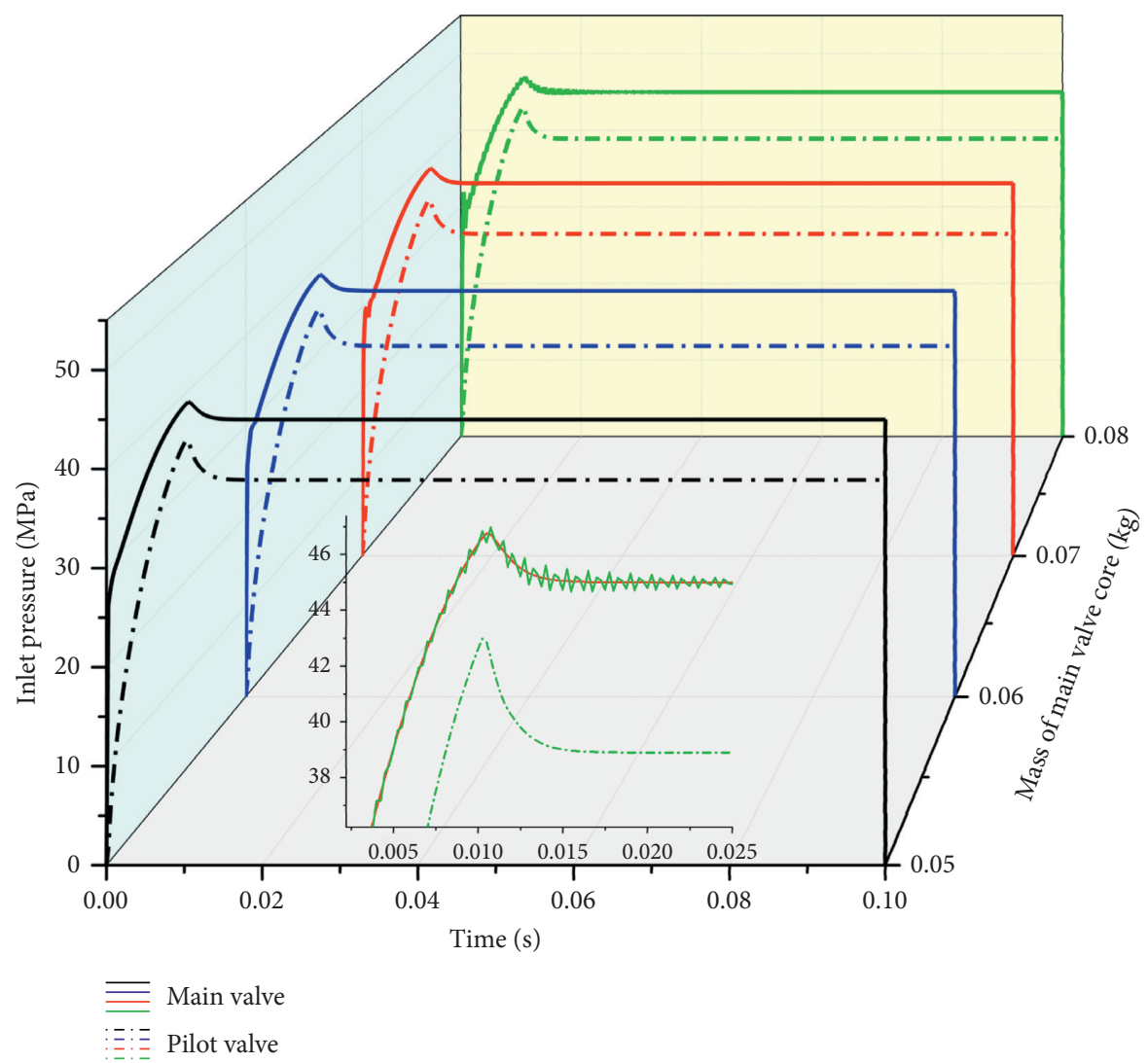

FIGURE 14: Influence of main valve-core mass on pressure.

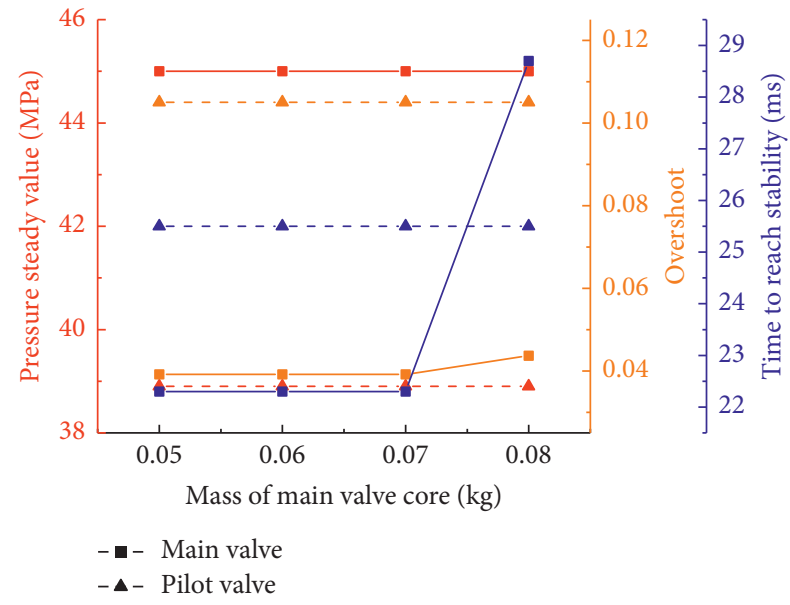

FIgURe 15: Dynamic response indexes.

pressure change areas at the valve seat hole are triangular and the pressure distributions are dense, and there are local high-pressure zones on the wall below the valve seat holes, easy to cause cavitation damage on the wall.

(4) Chamfer of Main Valve Damping Hole. The chamfer of main valve damping hole is changed under the same constraints and other structural parameters, and the simulation is carried out separately.

The pressure distribution near main valve damping hole under stable condition is obtained, as is shown in Figure 25.
As can be seen from Figure 25, when main valve damping hole is not chamfered, the orifice pressure at main valve damping hole distributes uniformly, and there is no obvious pressure stratification area. When the chamfer of main valve damping hole is 45 degrees, there are obvious low-pressure areas on both sides of the damping hole, and the pressure at the central part of main valve damping hole is higher; therefore, cavitation and eddy current are easy to occur at main valve damping hole. When the chamfer of main valve damping hole is arc, the pressure near the damping hole is layered uniformly, and there is no obvious low-pressure area.

3.4.2. Optimization of Internal Structure. Through the analysis of the influencing factors of the overall flow field of relief valve, the internal structure of relief valve is determined as shown in Table 4.

Figure 26 shows the flow field distribution of $\mathrm{X}-\mathrm{O}-\mathrm{Y}$ section under the steady state of relief valve.

From the simulation results, it can be seen that the pressure distribution of relief valve is uniform, the high pressure zone is from main valve inlet cavity to pilot valve damping hole, and the pressure change is intensive at main valve outlet; the streamline of main valve lower cavity and piston surface to the outlet is uniform, with no obvious eddy flow area. The flow velocity at main valve outlet is the fastest, with obvious jet region, and the turbulent kinetic energy at the valve port is the largest. The oil on the piston surface of 


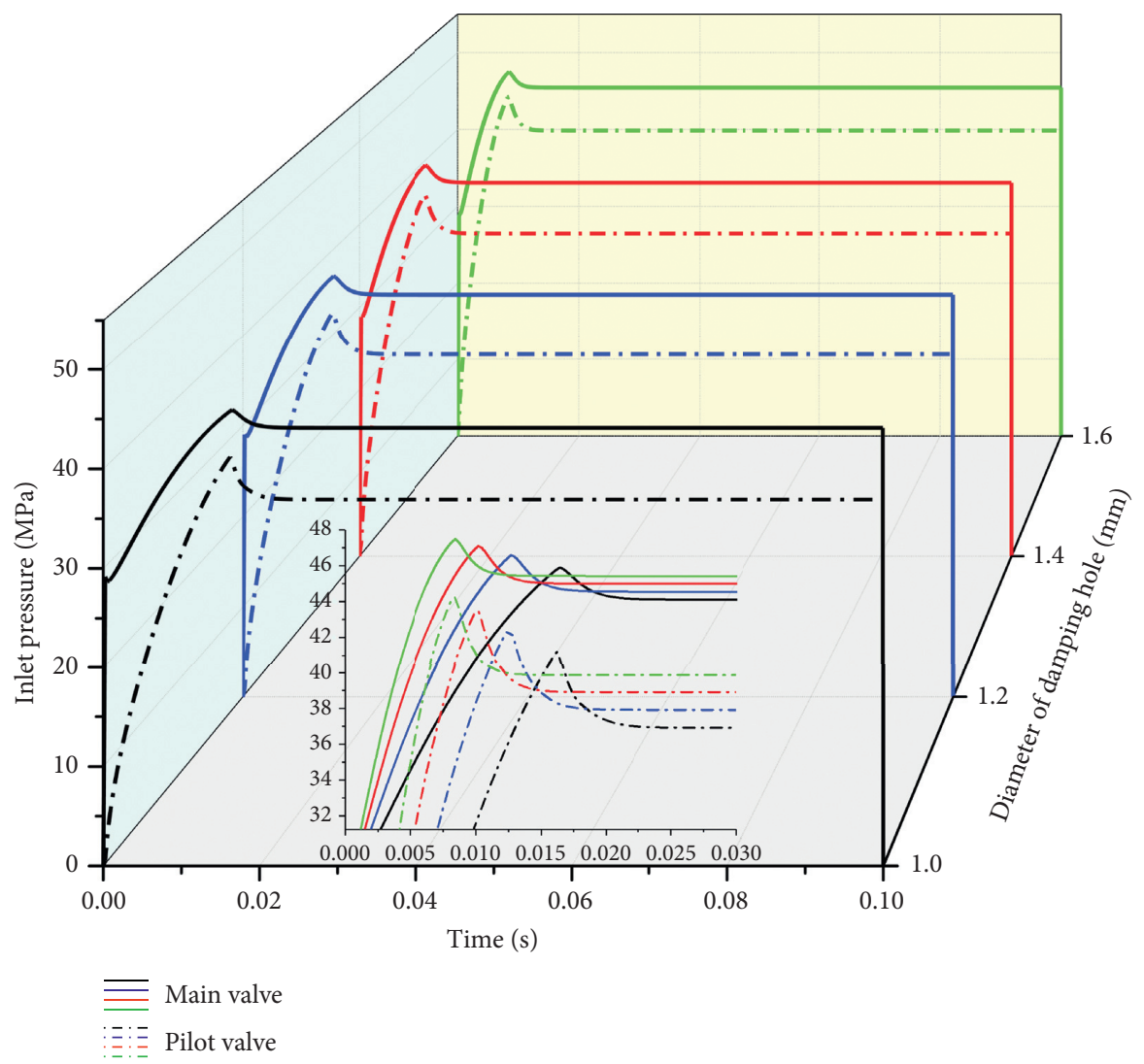

FIgURE 16: Influence of damping holes diameter.

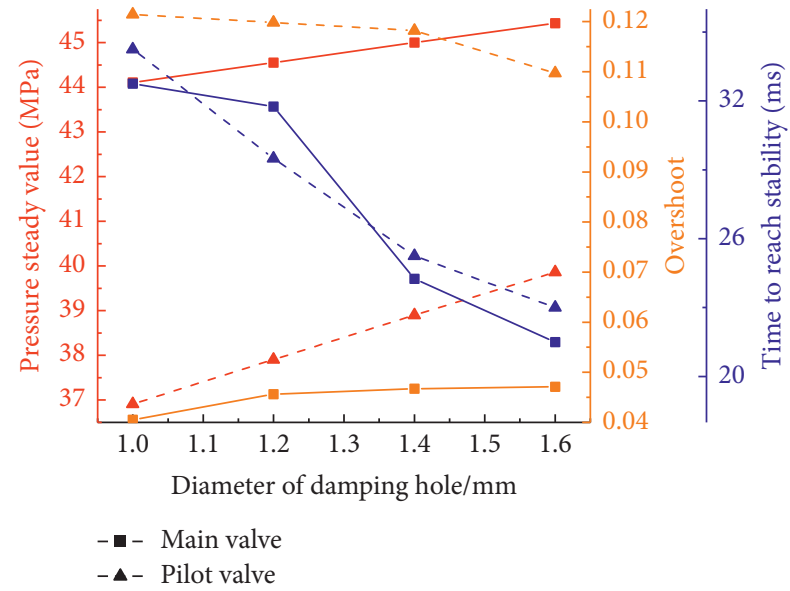

Figure 17: Dynamic response indexes.

main valve converges that under the outlet chamber, and the two streamlines intersect, where the turbulent kinetic energy is larger. Therefore, the structure of relief valve meets the requirements of operation, and the structure scheme is reasonable and feasible.

3.5. Cosimulation of Digital Relief Valve. The physical structure and control model of digital relief valve are jointly simulated, and the cosimulation result of digital relief valve is obtained. The results of AMESim simulation and Simulink simulation obtained above are compared with the cosimulation result, as is shown in Figure 27.

As can be seen from Figure 27, compared with the dynamic characteristics results simulated by AMESim and Simulink separately, the time in the cosimulation result to reach stable state is $9.07 \mathrm{~ms}$ due to the adoption of the digital control system, which is significantly shortened with no pressure overshoot. It shows that the designed digital relief valve can quickly and stably meet working requirements. When the actual pressure detected by the control system is different from the setting pressure, the pretightening force of relief valve regulating spring is changed by adjusting the pulse number of the stepper motor. Thus, the pressure of relief valve is adjusted, and then the pressure of relief valve will fluctuate in a zigzag form. The pressure fluctuation is gradually reduced and finally tends to be stable due to the function of Proportional-Integral-Derivative (PID) controller. The cosimulation result of digital relief valve is closer to its actual working characteristics; therefore, the method of AMESim and Simulink cosimulation is feasible and effective.

The working pressure of the digital relief valve is changed and other parameters are kept unchanged. The hydraulic system is simulated, and the cosimulation results of the digital relief valve are shown in Figure 28(a). The flow of the hydraulic system is changed by adjusting the displacement of the variable pump, and then, through the simulation, the working pressures of digital relief valve under different flows are shown in Figure 28(b). 


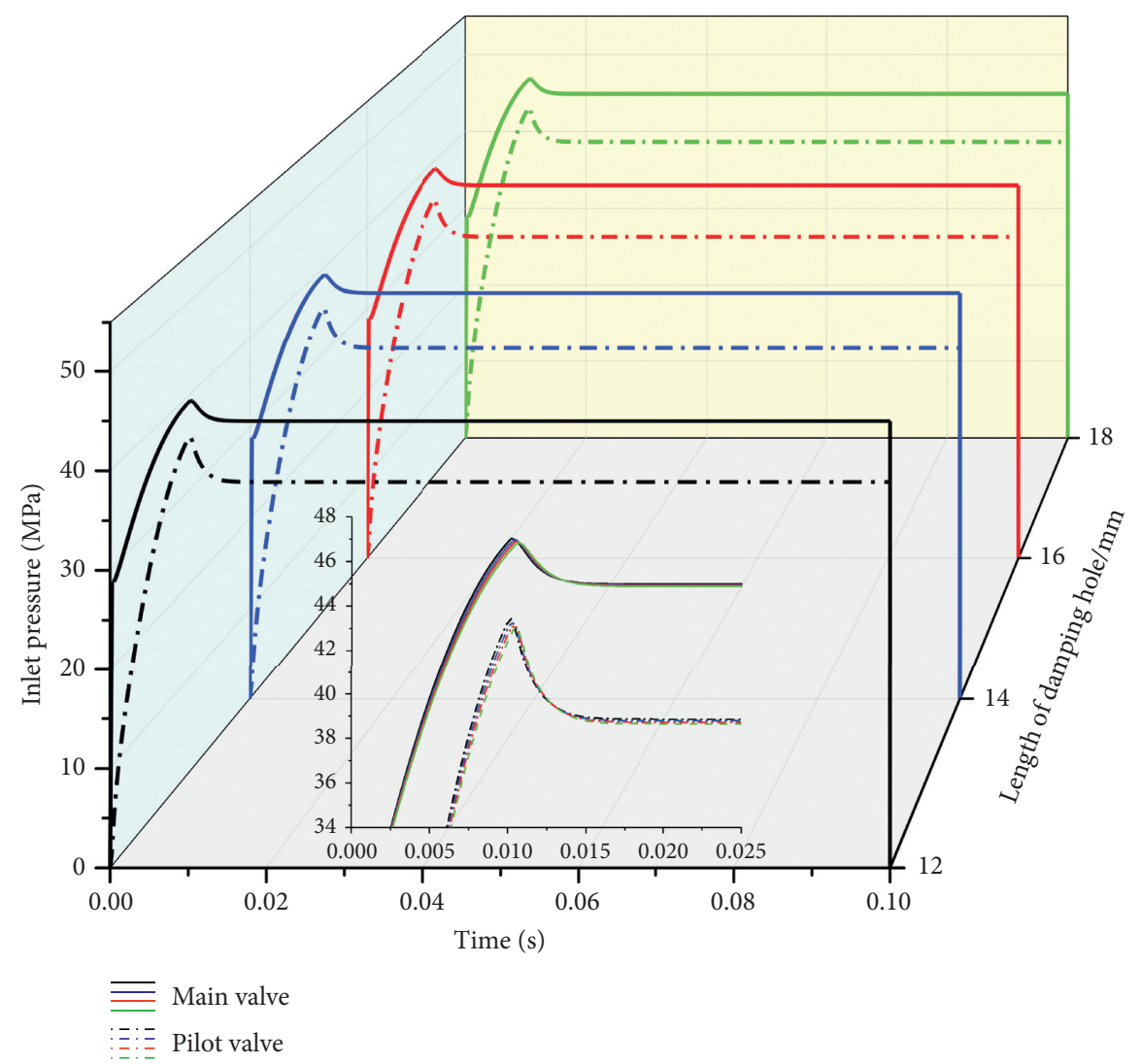

Figure 18: Influence of damping holes length.

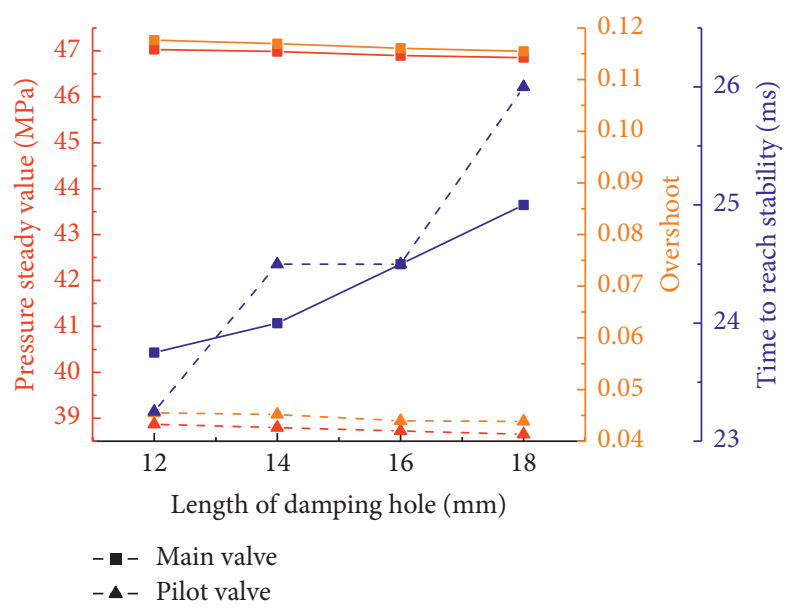

FIGURE 19: Dynamic response indexes.

TABLE 3: Optimized structural parameters of relief valve.

\begin{tabular}{lcc}
\hline Structural parameter & Initial value & Optimized value \\
\hline Stiffness of pilot valve spring $(\mathrm{N} / \mathrm{mm})$ & 14.3 & 14.4 \\
Stiffness of main valve spring $(\mathrm{N} / \mathrm{mm})$ & 9.038 & 9.3 \\
Diameter of pilot valve damping hole $(\mathrm{mm})$ & 1.2 & 1.4 \\
Diameter of main valve damping hole $(\mathrm{mm})$ & 1.2 & 1.4 \\
Length of pilot valve damping hole $(\mathrm{mm})$ & 14.4 & 12 \\
Length of main valve damping hole $(\mathrm{mm})$ & 14.4 & 12 \\
\hline
\end{tabular}

Note: the remaining structural parameters are consistent with the initial parameters in Table 2. 


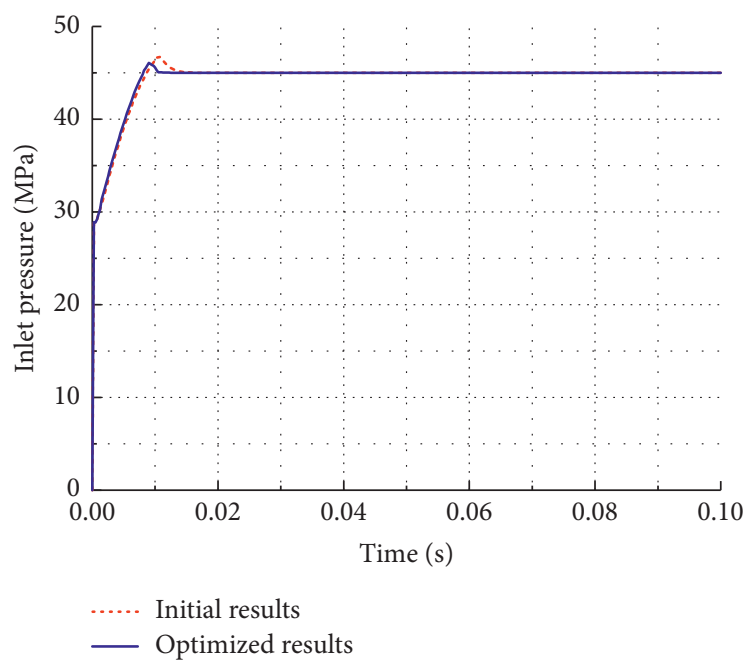

Figure 20: Comparison between initial results and optimized results.

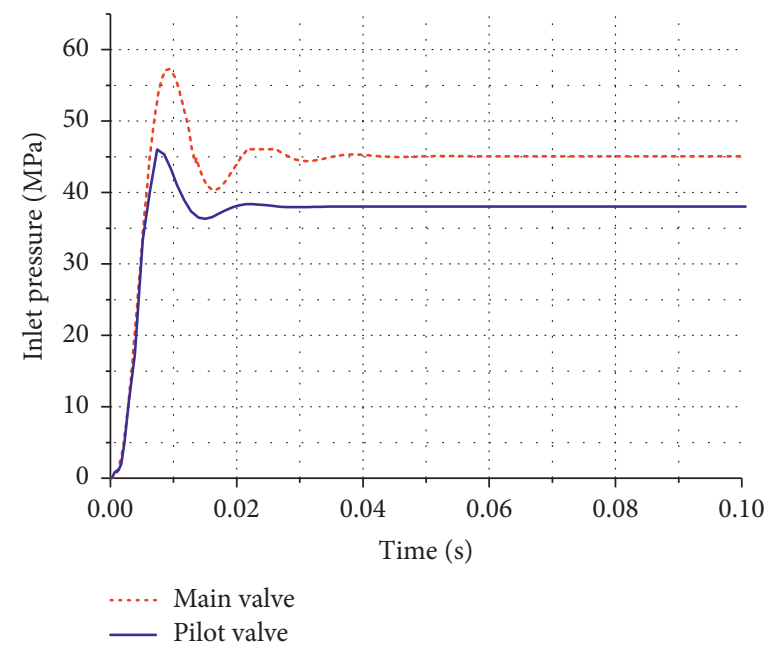

Figure 21: Dynamic response curves of pilot valve and main valve.

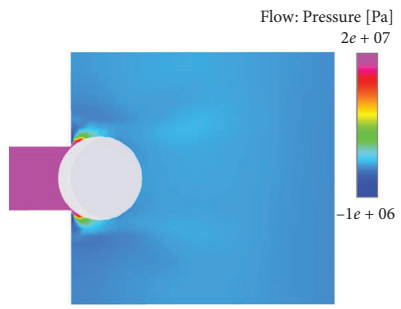

(a)

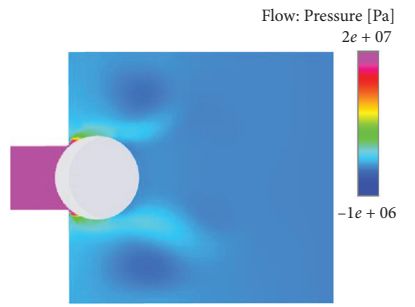

(b)

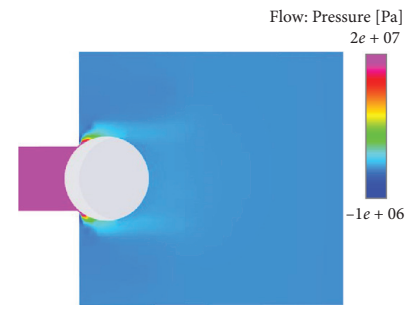

(c)

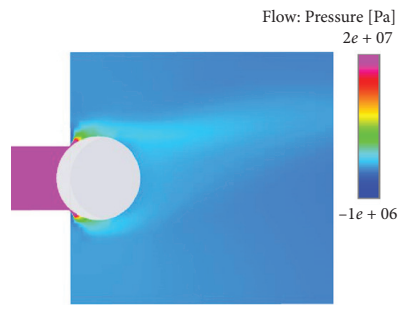

(d)

Figure 22: Pressure distribution near pilot valve seat hole under stable condition. (a) Without chamfer. (b) 20-degree chamfer. (c) 45-degree chamfer. (d) Arc chamfer.

As can be seen from Figure 28(a), when the working pressure increases, the pressure oscillation amplitude at the start-up moment decreases, the response speed of the digital relief valve increases, the fluctuation with zigzag form amplitude increases, and the oscillation period shortens; thus, the time to reach the stable state is shortened. As can be seen from Figure 28(b), the change of flow has little influence on the response speed of digital relief valve. But the working pressure of digital relief valve increases with the increase of flow, and the amplitude of pressure oscillation generated at the moment of start-up increases; thus, the hydraulic impact of the system increases. 


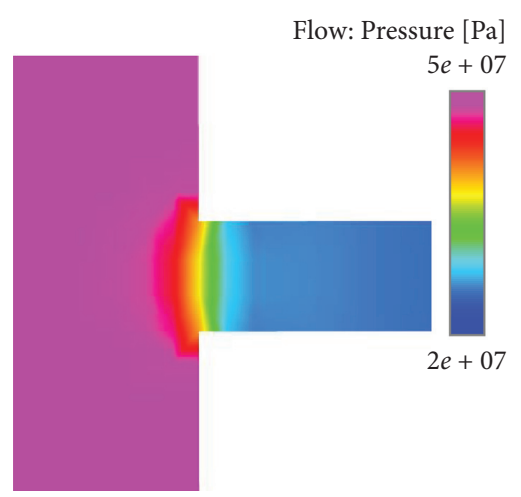

(a)

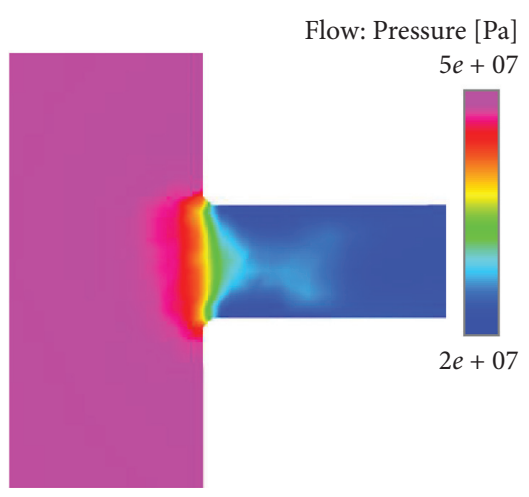

(b)

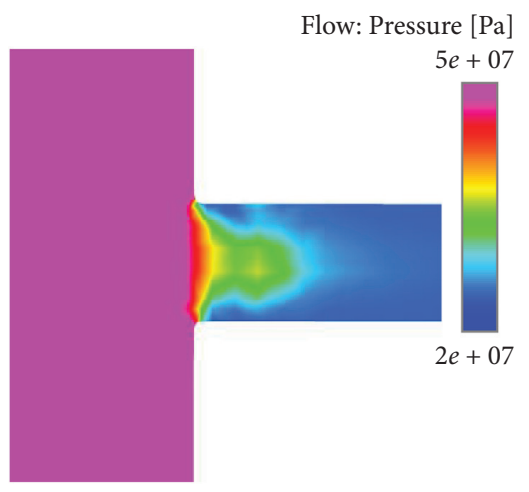

(c)

Figure 23: Pressure distribution near damping hole under stable condition. (a) Without chamfer. (b) 45-degree chamfer. (c) Arc chamfer.

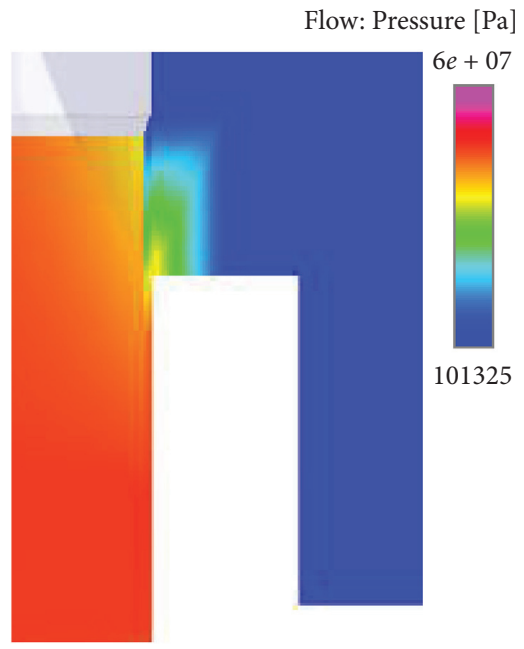

(a)

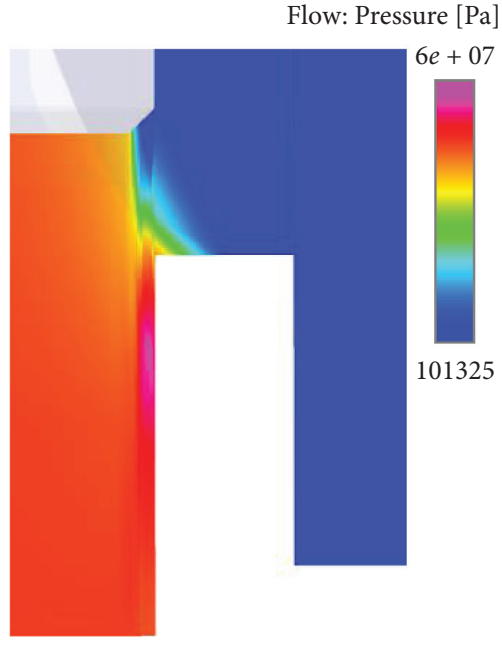

(b)

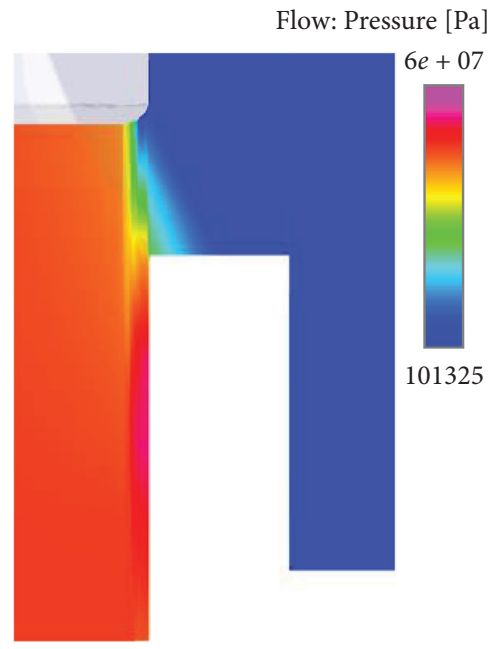

(c)

Figure 24: Pressure distribution near main valve seat hole under stable condition. (a) 30-degree chamfer. (b) 45-degree chamfer. (c) Arc chamfer.

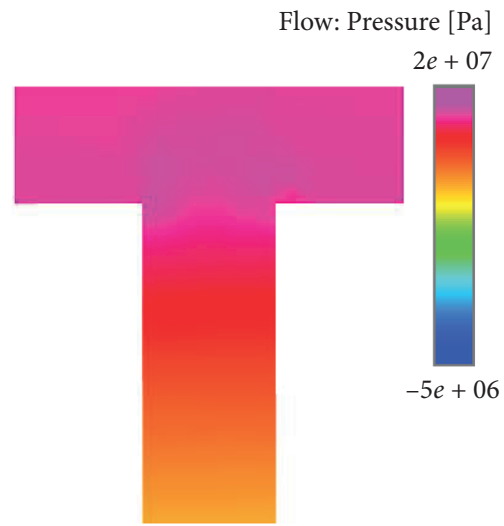

(a)
Flow: Pressure $[\mathrm{Pa}]$

$2 e+07$

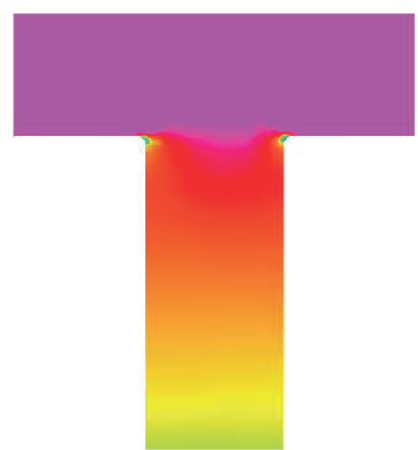

(b)
Flow: Pressure [Pa]

$2 e+07$

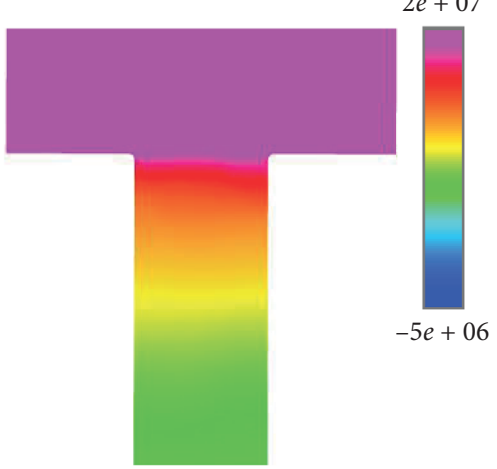

(c)

Figure 25: Pressure distribution near damping hole under stable condition. (a) Without chamfer. (b) 45-degree chamfer. (c) Arc chamfer.

The developed digital emulsion relief valve is installed on high-pressure large flow emulsion pump, as is shown in Figure 29. The test system includes mechanical system, hydraulic system, data acquisition, and analysis system, which can carry out pressure-regulating range, pressure loss test, opening and closing characteristic test, and dynamic response characteristic test.

Through the cosimulation of hydraulic system under working conditions of different pressures and flows, the 
TABLE 4: Internal structure of relief valve.

\begin{tabular}{lcc}
\hline No. & Structural parameter & Chamfer \\
\hline 1 & Seat hole of pilot valve & 45 -degree chamfer \\
2 & Seat hole of main valve & 30 -degree chamfer \\
3 & Damping hole of pilot valve & Without chamfer \\
4 & Damping hole of main valve & Without chamfer \\
\hline
\end{tabular}

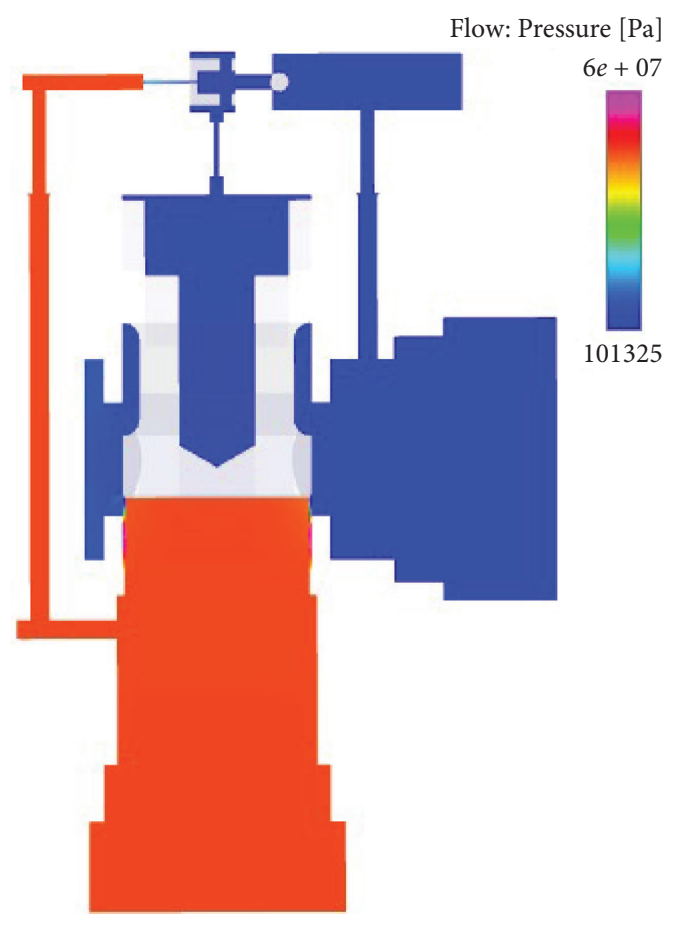

(a)

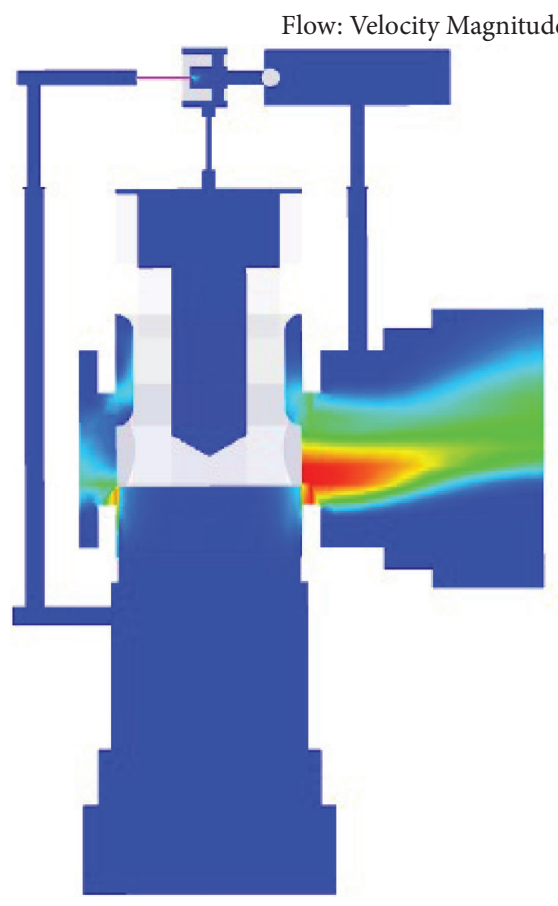

(c)

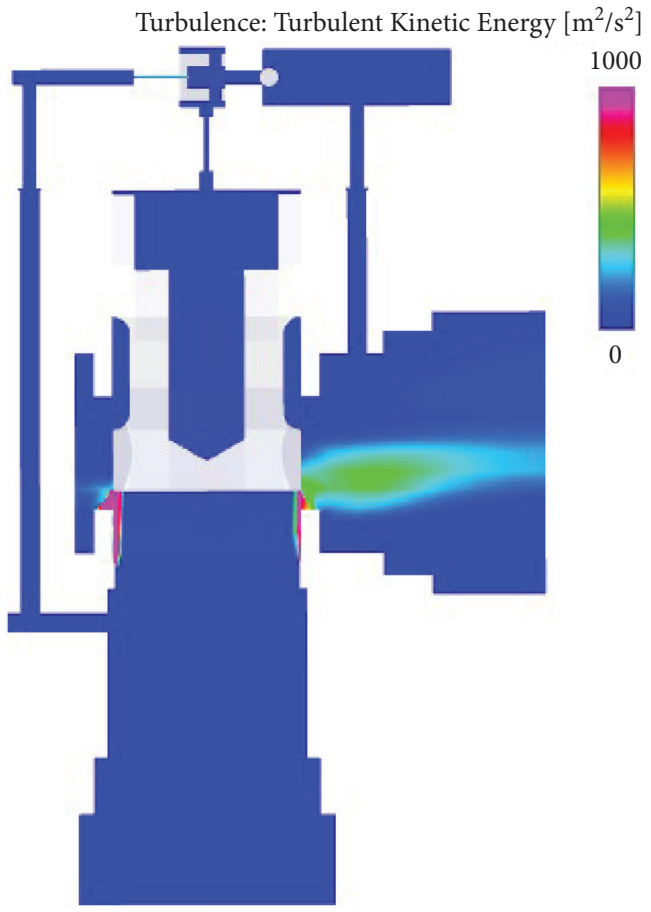

(b)

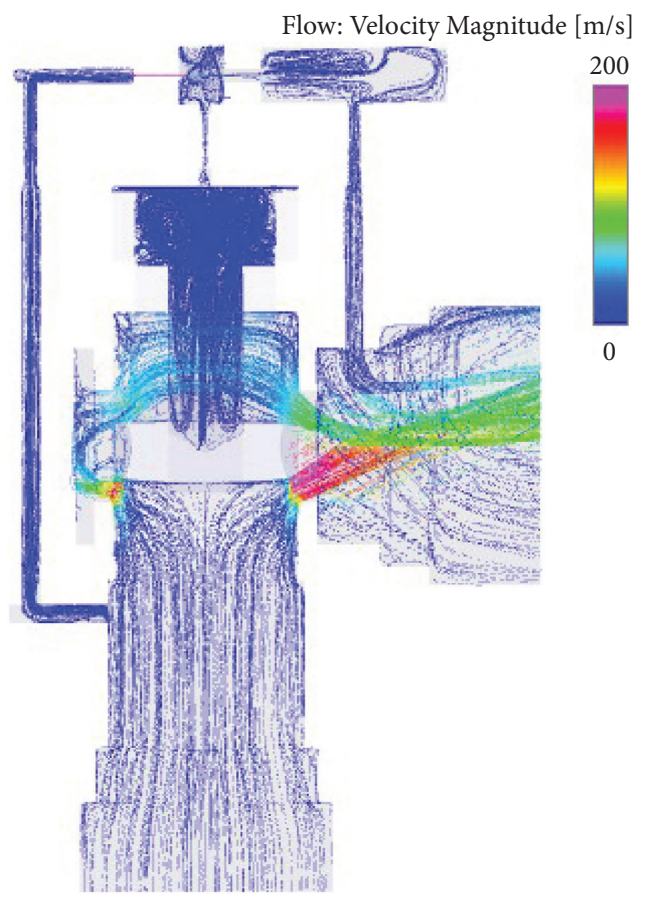

(d)

FIgure 26: The cloud charts of flow field distribution. (a) Pressure distribution. (b) Turbulent kinetic energy distribution. (c) Velocity distribution. (d) Velocity streamline diagram. 


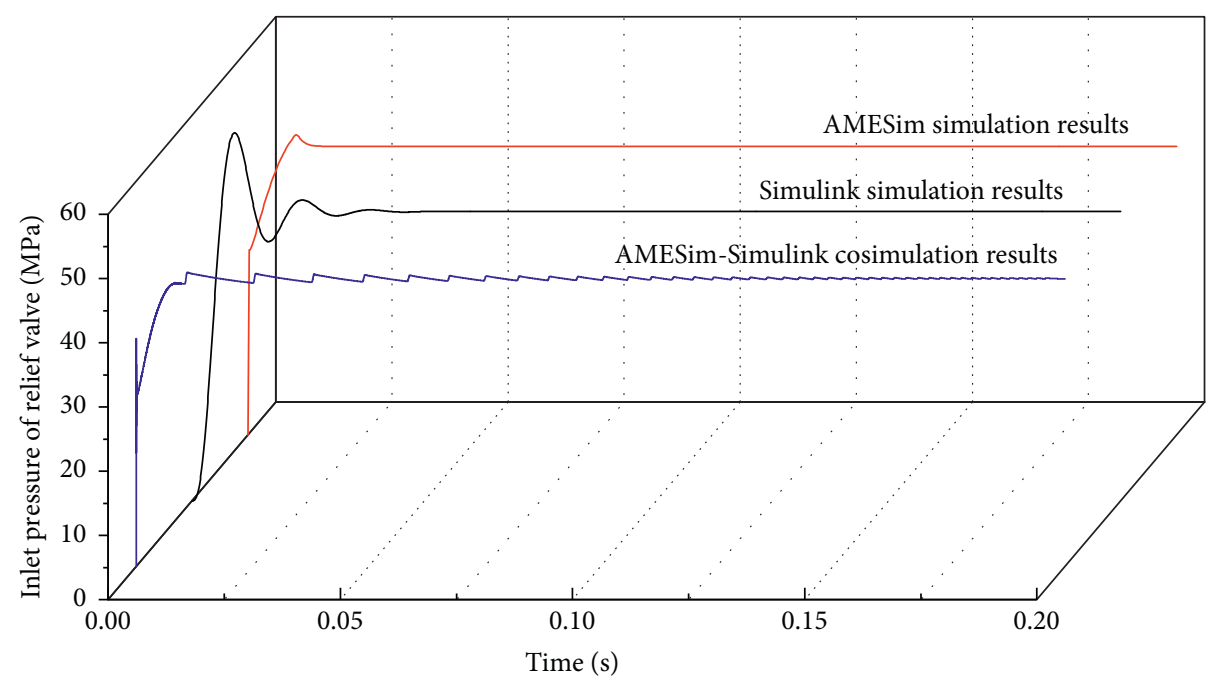

Figure 27: Comparison of simulation results.

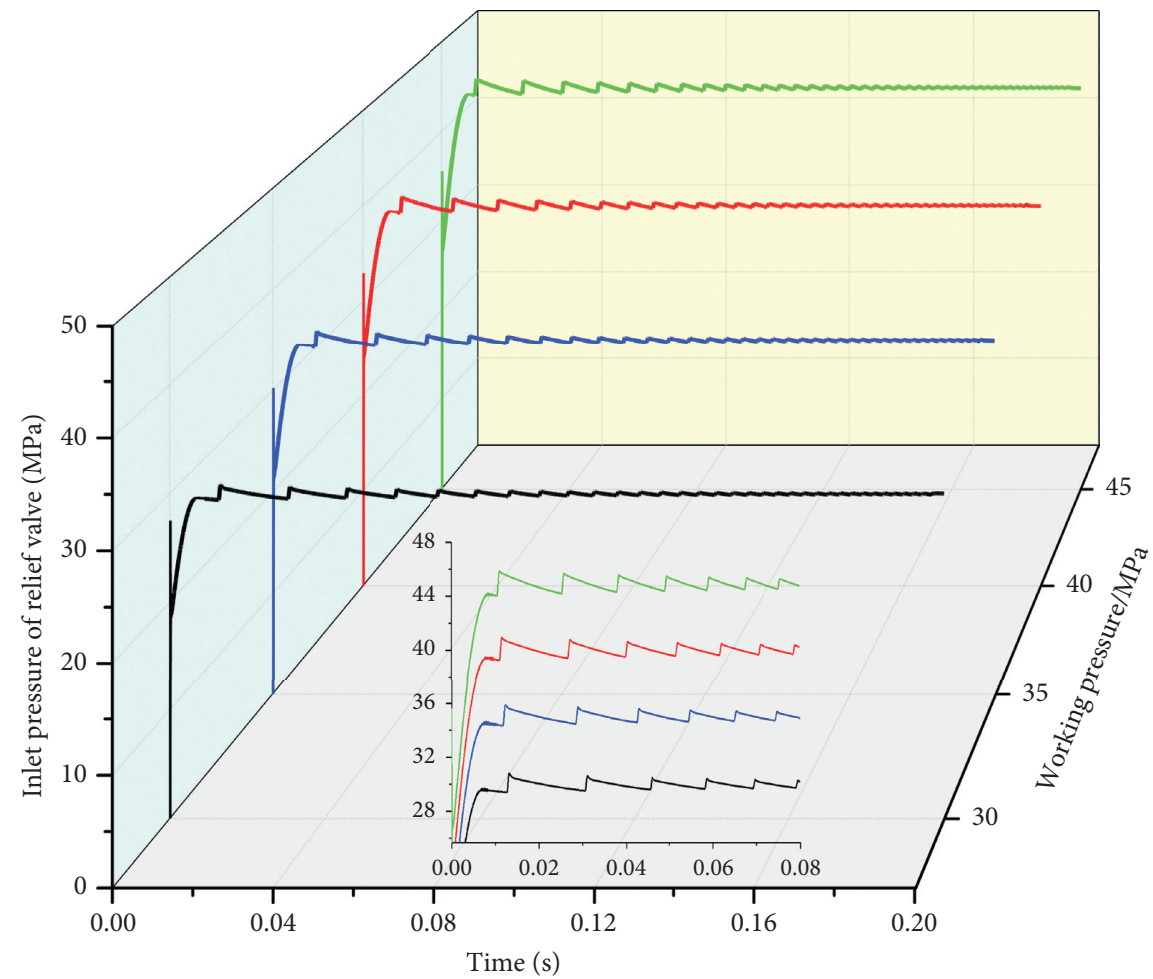

(a)

FIgure 28: Continued. 


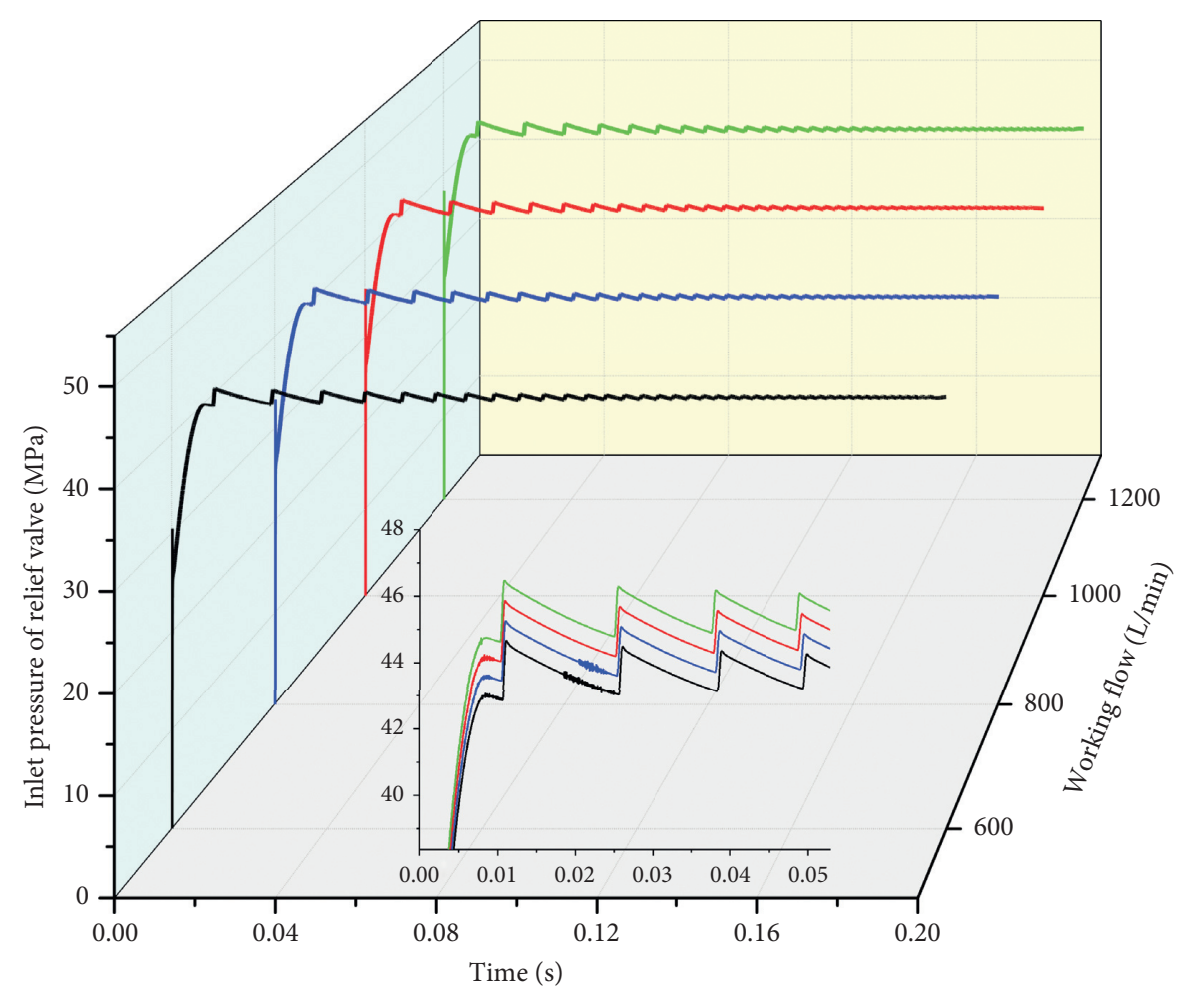

(b)

Figure 28: Pressure curves of digital relief valve. (a) Under different working pressure. (b) Under different working flow.

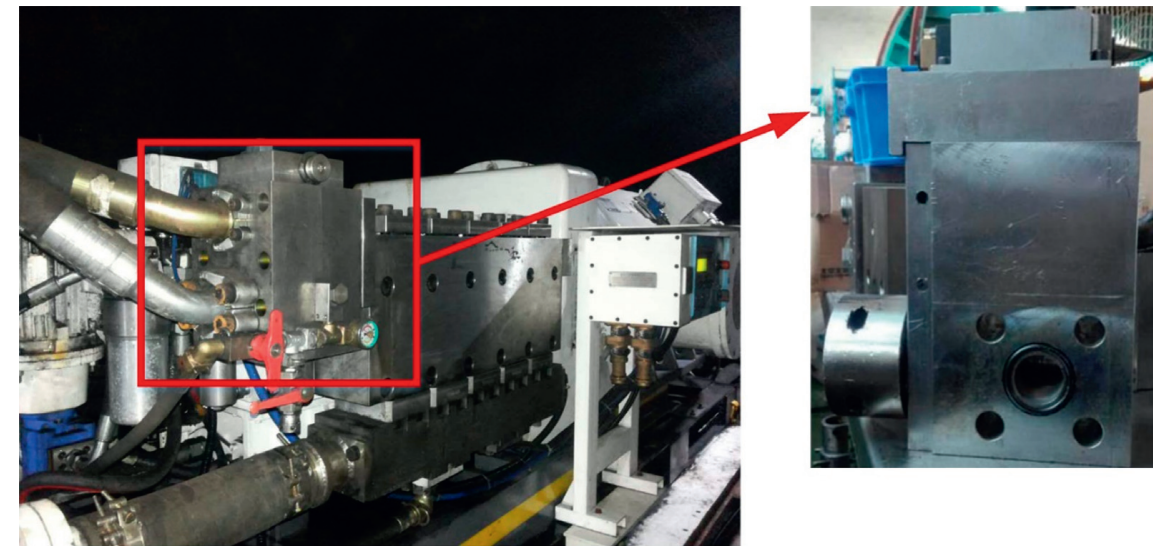

FIgURE 29: The physical structure of relief valve.

influence of working pressure and system flow on the performance of digital relief valve is analyzed. The analysis shows that the control system of digital relief valve can improve the working characteristics of relief valve, and, in actual working environment, digital relief valve can adjust working pressure in time. The digital relief valve meets working requirements, with good dynamic characteristics. Through test analysis, the response time of pressure regulation is short, with good flow rate and pressure stability, which verifies the correctness of relief valve design.

\section{Conclusion}

In this paper, the dynamic and flow field characteristics of large flow emulsion digital relief valve were analyzed. Meanwhile, the research of electrohydraulic cosimulation of digital relief valve was carried out. The theoretical basis for the structural design of relief valve was provided.

The analysis results obtained by AMESim simulation showed that spring stiffness, core mass, diameter, and length of damping hole are the main structural parameters affecting working characteristic. By analyzing the optimized structure 
model, the time to reach stability reduced by $27.8 \%$ and the pressure overshoot decreased by $45.5 \%$ when compared to the results before optimization. The analysis results obtained by Simulink simulation also showed that relief valve had good performance.

The flow field analysis of relief valve was carried out by using PumpLinx. Considering the transient and stable state of relief valve, the influences of different structural features on the field distribution and the overall dynamic performance are compared and analyzed. The results show that the flow field distribution and the overall dynamic performance of digital relief valve are more reasonable when the damping holes of main valve and pilot valve are not chamfered, with the chamfer of pilot valve seat hole of 45 degrees and the chamfer of pilot valve seat hole of 30 degrees.

The digital relief valve was analyzed by AMESimSimulink cosimulation. The results show that the dynamic working characteristics of relief valve can be improved by the digital control system. Under different working pressures and flows, the time to reach stable state is shorter, and the pressure overshoot is zero. Therefore, it has good working characteristics of real-time dynamic pressure regulation, and the correctness of the relief valve design is verified by test analysis. However, the parameters of control system also play a vital role in the performance of digital relief valve; therefore, its optimization will be the next important research work.

\section{Abbreviations}

CFD: Computational fluid dynamics

PID: Proportional-integral-derivative

$p_{1}$ : Inlet pressure of pilot valve

$A_{x}$ : The area of pilot valve seat hole

$m$ : Mass of pilot valve-core

$B_{x}$ : Kinematic viscous damping coefficient of pilot valvecore

$K_{x}: \quad$ Spring stiffness of pilot valve

$x_{0}: \quad$ Precompression of pilot valve spring

$K_{s x}: \quad$ Hydrodynamic force stiffness of pilot valve port

$q_{1}$ : $\quad$ Flow rate of pilot valve damping hole

$G_{1}$ : Liquid guide of pilot valve damping hole

$p: \quad$ Inlet pressure of main valve

$q_{2}$ : $\quad$ Flow rate of main valve upper cavity

$V_{1}$ : Volume of pilot valve front cavity

$E$ : $\quad$ Elastic modulus of emulsion

$K_{q x}$ : Flow gain of pilot valve port

$K_{c x}$ : Pressure-flow gain of pilot valve port

$p_{2}$ : $\quad$ Pressure of main valve upper cavity

$A_{1}$ : Area of main valve lower cavity

$A_{2}$ : Area of main valve upper cavity

$M$ : $\quad$ Mass of main valve-core

$y: \quad$ Displacement of main valve-core

$B_{y}$ : Kinematic viscous damping coefficient of main valvecore

$K_{y}: \quad$ Spring stiffness of main valve

$y_{0}$ : Precompression of main valve spring

$K_{s x}: \quad$ Hydrodynamic force stiffness of main valve port

$q$ : $\quad$ Flow rate of relief valve
$V_{0}: \quad$ Volume of main valve inlet cavity

$K_{q y}:$ Flow gain of main valve port

$K_{c y}$ : Pressure-flow gain of pilot valve port

$G_{2}$ : Liquid guide of main valve damping hole

$V_{2}$ : Volume of main valve upper cavity

$g_{m}: \quad$ Gain of stepping motor

$\lambda: \quad$ Step of stepping motor.

\section{Data Availability}

The data used to support the findings of this study are available from the corresponding author upon request.

\section{Conflicts of Interest}

The authors declare that there are no conflicts of interest regarding the publication of this paper.

\section{Acknowledgments}

This research was supported by Special funds for Climbing Project of Taishan Scholars, the National Natural Science Foundation of China (Grant no. 51674155), Innovative Team Development Project of Ministry of Education (Grant no. IRT_16R45), Shandong Natural Science Foundation (Grant no. ZR201807080343), Key R\&D Projects in Shandong Province (Grants nos. 2019SDZY01 and 2018GGX103027), and Qingdao Source Innovation Plan Project (Grant no. 182-2-20-jch).

\section{References}

[1] J. Wang and J. Zhang, "Research on high-power and highspeed hydraulic impact testing machine for mine anti-impact support equipment," Shock and Vibration, vol. 2019, p. 12, Article ID 6545980, 2019.

[2] L. Wan, H. Dai, Q. Zeng, Z. Sun, and M. Tian, "Characteristic analysis and co-validation of hydro-mechanical continuously variable transmission based on the wheel loader," Applied Sciences, vol. 10, no. 17, p. 5900, 2020.

[3] F. Majdič, "Design and testing of a two-stage water-hydraulics pressure-relief valve," in New Technologies, Development and Application III, pp. 48-58, Springer, New York, NY, USA, 2020.

[4] W. Ma and T. Pan, "Experimental research on the dynamic instability and water hammer effect of pressure relief valve," International Journal of Fluid Machinery and Systems, vol. 13, no. 1, pp. 150-159, 2020.

[5] C. Zhaoyi, "Research and analysis of outlet flow of relief valve pilot valve," in Proceedings of the 2019 IEEE 8th International Conference on Fluid Power and Mechatronics (FPM), pp. 117-121, Wuhan, China, April 2019.

[6] K. Dasgupta and J. Watton, "Dynamic analysis of proportional solenoid controlled piloted relief valve by bondgraph," Simulation Modelling Practice and Theory, vol. 13, no. 1, pp. 21-38, 2005.

[7] K. Dasgupta and R. Karmakar, "Dynamic analysis of pilot operated pressure relief valve," Simulation Modelling Practice and Theory, vol. 10, no. 1-2, pp. 35-49, 2002.

[8] Y. Shu-Jun, J. Chong-Bo, and H. Ji-Bin, "Study on the PWM digital proportional relief valve," Chinese Hydraulics \& Pneumatics, vol. 2005, no. 3, pp. 46-49, 2005. 
[9] Q. Hao, W. Wu, X. Liang, and Z. Liu, "Effects of structure parameters on abnormal opening of pilot-operated relief valve under alternating pressure," IEEE Access, vol. 7, pp. 3393233942, 2019.

[10] W. Wei, H. Jian, Q. Yan, X. Luo, and X. Wu, "Nonlinear modeling and stability analysis of a pilot-operated valvecontrol hydraulic system," Advances in Mechanical Engineering, vol. 10, no. 11, Article ID 1687814018810660, 2018.

[11] H. E. Xiaofeng, "Numerical simulation on the dynamic characteristics of a two-stage water hydraulic relief valve," Chinese Journal of Mechanical Engineering, vol. 42, pp. 75-80, 2006.

[12] Y. Li, F. Ding, and Y. Shen, "Steady-state characteristics of proportional pilot-operated relief valve with low power consumption," Chinese Journal of Mechanical Engineering, vol. 21, no. 24, pp. 2921-2925, 2010.

[13] O. Gad, "Comprehensive nonlinear modeling of a pilot operated relief valve," Journal of Dynamic Systems, Measurement, and Control, vol. 135, no. 1, 011011 pages, 2012.

[14] Y. B. Yin, J. Y. Yuan, and J. Y. Fu, "Characteristics of two-stage relief valve with series damping orifice in the front chamber of pilot valve," Journal of Jilin University, vol. 47, no. 1, pp. 129-136, 2017.

[15] S. Morselli, S. Gessi, P. Marani, M. Martelli, and C. M. R. D. Hieronymis, "Dynamics of pilot operated pressure relief valves subjected to fast hydraulic transient," AIP Conference Proceedings, vol. 2191, no. 1, 020116 pages, 2019.

[16] X. Mao, B. Li, Y. Liu, J. Hu, and Q. Lai, "Design \& simulation of a hydraulic back pressure valve with a large flow range," Journal of Physics Conference Series, vol. 1213, Article ID 042023, 2019.

[17] X. Mao, J. Hu, C. Wu, Y. Liu, and Y. Liu, "Characteristic analysis of a water hydraulic pilot-operated pressure-reducing valve," IOP Conference Series: Earth and Environmental Science, vol. 69, Article ID 012072, 2017.

[18] X. Mao, W. Duan, B. Li, C. Wu, and Y. Liu, "Structural optimization of a water hydraulic pilot-operated pressurereducing valve," IOP Conference Series: Earth and Environmental Science, vol. 199, Article ID 052007, 2018.

[19] X. Lei and Y. Wu, "Simulation and result analysis of AMEsim for the relief valve dynamic characteristics experiment," in Proceedings of the 2010 International Conference on Electrical \& Control Engineering, Wuhan, China, June 2010.

[20] Q.-1. Zeng, M.-q. Tian, L.-r. Wan et al., "Characteristic analysis of digital large flow emulsion relief valve," Mathematical Problems in Engineering, vol. 2020, Article ID 5820812, 18 pages, 2020.

[21] L. Yang, Z. Wang, W. Dempster, X. Yu, and S.-T. Tu, "Experiments and transient simulation on spring-loaded pressure relief valve under high temperature and high pressure steam conditions," Journal of Loss Prevention in the Process Industries, vol. 45, pp. 133-146, 2017.

[22] R. Finesso and M. Rundo, "Numerical and experimental investigation on a conical poppet relief valve with flow force compensation," International Journal of Fluid Power, vol. 18, no. 2, pp. 111-122, 2017.

[23] S. Jang and J. Kang, "Orifice design of a pilot-operated pressure relief valve," Journal of Pressure Vessel Technology, vol. 139, no. 3, 10 pages, Article ID 031601, 2016.

[24] C. J. Tian, Y. W. Zhang, J. Wang, G. F. Ru, and J. Q. Yan, "Design and performance analysis of digital pressure relief valve of water-based hydraulic," Applied Mechanics \& $M a$ terials, vol. 387, pp. 369-373, 2013.
[25] X. Yuan and K. Guo, "Modelling and analysis for a pilot relief valve using CFD method and deformation theory of thin plates," Science China Technological Sciences, vol. 58, no. 6, pp. 979-998, 2015.

[26] J. Bossard, A. Reich, and A. DiMeo, "Dynamic analysis of a high-pressure relief valve during opening," Journal of Pressure Vessel Technology, vol. 143, no. 1, Article ID 011403, 5 pages, 2020. 